\title{
Harvested log damage and value loss associated with two ground-based harvesting systems in central Appalachia
}

\author{
Michael R. Vanderberg \\ West Virginia University
}

Follow this and additional works at: https://researchrepository.wvu.edu/etd

\section{Recommended Citation}

Vanderberg, Michael R., "Harvested log damage and value loss associated with two ground-based harvesting systems in central Appalachia" (2002). Graduate Theses, Dissertations, and Problem Reports. 1294.

https://researchrepository.wvu.edu/etd/1294

This Thesis is protected by copyright and/or related rights. It has been brought to you by the The Research Repository @ WVU with permission from the rights-holder(s). You are free to use this Thesis in any way that is permitted by the copyright and related rights legislation that applies to your use. For other uses you must obtain permission from the rights-holder(s) directly, unless additional rights are indicated by a Creative Commons license in the record and/ or on the work itself. This Thesis has been accepted for inclusion in WVU Graduate Theses, Dissertations, and Problem Reports collection by an authorized administrator of The Research Repository @ WVU. For more information, please contact researchrepository@mail.wvu.edu. 


\title{
HARVESTED LOG DAMAGE AND VALUE LOSS ASSOCIATED WITH TWO GROUND-BASED HAR VESTING SYSTEMS IN CENTRAL APPALACHIA
}

\author{
by \\ Michael R. Vanderberg \\ Thesis submitted to the \\ Davis College of Agriculture, Forestry, and Consumer Sciences \\ at West Virginia University \\ in partial fulfillment of the requirements for the degree of
Master of Science
in
Forestry \\ Approved by \\ Dr. Jingxin Wang, Committee Chairperson \\ Dr. Joe McNeel \\ Dr. Darrell Dean
}

Wood Industries

Morgantown, West Virginia

2002

Keywords: Log damage, Timber harvesting, Forest operations 


\begin{abstract}
HARVESTED LOG DAMAGE AND VALUE LOSS ASSOCIATED WITH TWO GROUND-BASED HAR VESTING SYSTEMS IN CENTRAL APPALACHIA
\end{abstract}

\title{
by Michael R. Vanderberg
}

Damage is often seen as an important consideration when conducting partial harvests in hardwood stands, as excessive damage to residual trees will significantly reduce the potential value of the residual stand. Damage to harvested logs, especially hardwood saw and veneer logs can be an even more important concern relative to value loss associated with log degrade. The log damage and value loss were examined by harvesting system, felling function, species, and damage type in central Appalachia. Observations were made of all grade logs during the felling, skidding, decking/sorting, and loading functions of the harvesting operations. Saw logs or veneer logs sustaining damage to the bark or cambium were recorded with additional information obtained for damage location, damage volume, damage type, and possible cause of the damage. Data were analyzed statistically to determine and rank the phases of the harvesting process relative to potential damage and value loss to hardwood logs. Results indicated that, overall, manual harvesting systems cause more damage to harvested logs than mechanized harvesting systems, mostly due to the manual felling function. 


\section{DEDICATION}

The author wishes to dedicate this project to his long lost dog, Foster. He thanks him for his patience and his unconditional love, which was probably due to the food the author gave him, during this time of trial and tribulation. May he have many more days in the sun. 


\section{ACKNOWLEDGMENTS}

The author wishes to thank the United States Forest Service, especially the Northeastern Research Station for their support in this project. Other thanks goes to Dr. Jingxin Wang, Dr. Joe McNeel, and Dr. Darrell Dean of West Virginia University, and Dr. Chris LeDoux of the United States Forest Service, for their support and guidance throughout this project. More thanks goes to Matthew Malone of Allegheny Wood Products in Kingwood, WV and Mark Shreve of TrusJoist MacMillan in Buckhannon, WV for allowing research to be conducted on their harvesting operations. Also, thanks deserves to go to Glodfelty Logging Company, Paul Thomas \& Sons Logging, Roger Goodwin Logging, and Bill Robinson Logging for giving a student a break and allowing for a safe and interesting data collection environment. 


\section{TABLE OF CONTENTS}

Abstract

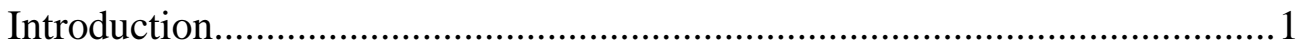

Chapter 1 - Literature Review
1.1 Background . .4
1.2 Log Damage During Felling.................................... 7
1.3 Log Damage During Bucking............................................10
1.4 Log Damage During Extraction, Decking, Loading, \& Hauling......12

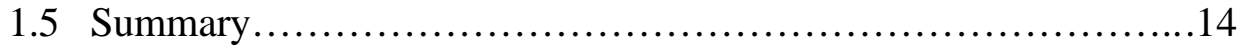

Chapter 2 - Methods and Data Collection

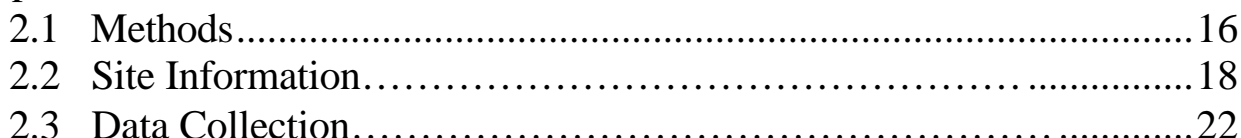

Chapter 3 - Data Analysis and Results

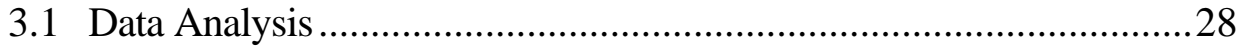

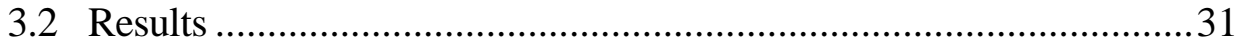

3.2.1 Saw Log Volume \& Value Loss. ..........................................31

3.2.1.1 Volume \& Value Loss by Harvesting Function.......34

3.2.1.2 Volume \& Value Loss by Species .......................... 35

3.2.1.3 Volume \& Value Loss by Damage Type ................. 37

3.2.1.4 Volume \& Value Loss by Log Grade ......................39

3.2.2 Veneer Value \& Degrade ......................................................4 41

3.2.3 Comparisons of Damage ....................................................42

3.2.3.1 Harvesting System ............................................42

3.2.3.2 Terrain Slope...................................................44

3.2.3.3 Harvesting Function...........................................45

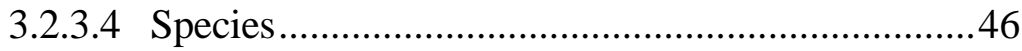

3.2.3.5 Damage Type................................................... 48

3.2.3.6 Log Grade ......................................................50

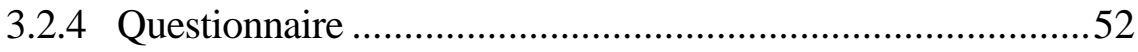


Chapter 4 - Summary and Discussion

4.1 Saw Log Volume and Value Loss .............................................55

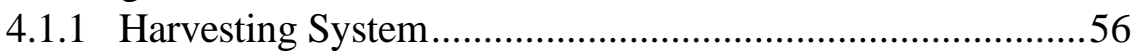

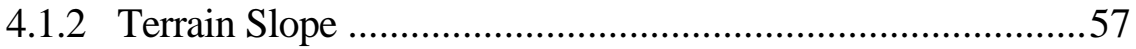

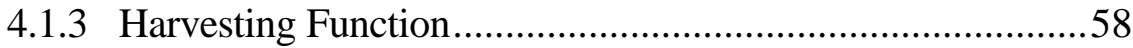

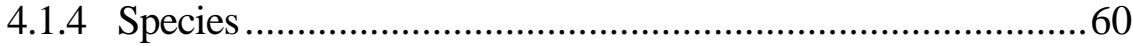

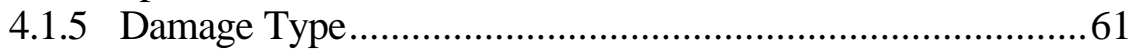

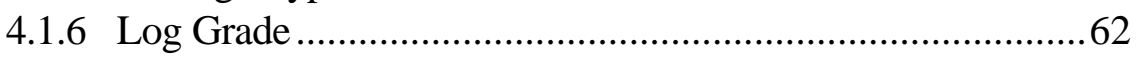

4.2 Veneer Log Value Loss .........................................................63

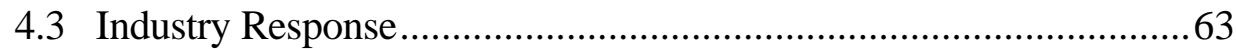

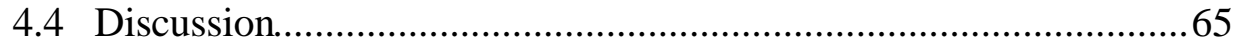

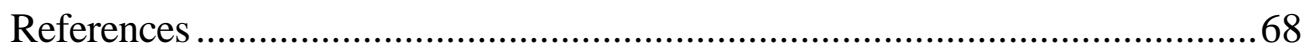

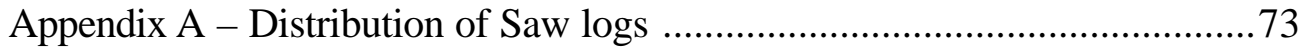

Appendix B - Total Volumes for Saw Logs ............................................. 81

Appendix C - Volume Losses for Saw Logs ............................................ 83

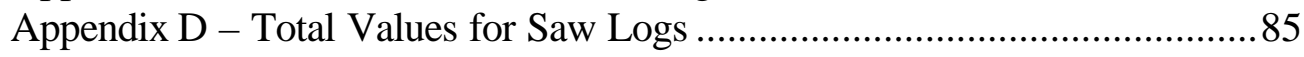

Appendix E - Value losses for Saw Logs...............................................8 87

Appendix F - Hardwood Log Volume and Value .......................................8 89

Appendix G - Hardwood Log Prices....................................................... 90

Appendix H - Questionnaire ............................................................. 91

Appendix I - Data Collection Sheet ........................................................ 93

Appendix J - Hardwood Saw Log Damage Pictures .................................... 95 


\section{LIST OF FIGURES}

Figure 2.1 - County Map...................................................................... 19

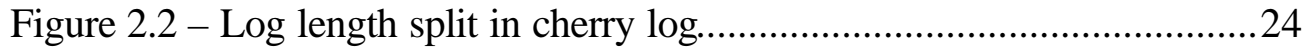

Figure 2.3 - Butt split in cherry $\log$..........................................................24

Figure 2.4 - Choker gouge on cherry $\log$............................................... 24

Figure 2.5 - Grapple tong gouge on red oak log...................................... 24

Figure 2.6 - Butt slab on cherry log caused by felling .............................. 24

Figure 2.7 - Butt slab on red oak log caused by felling ..............................2. 24

Figure 2.8 - Scrape on cherry log caused by skidding ................................225

Figure 2.9 - Scrape on chestnut oak log caused by skidding ....................... 25

Figure 2.10 - No woody tissue damage ..................................................... 25

Figure 2.11 - Frost crack in yellow-poplar $\log$........................................25 


\section{LIST OF TABLES}

Table 2.1 - Harvest equipment spread .................................................. 17

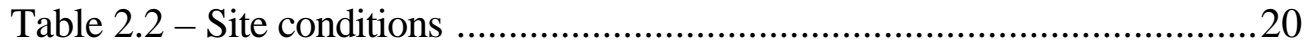

Table 2.3 - Site species composition.................................................... 21

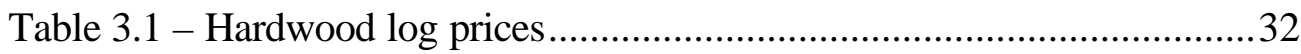

Table 3.2 - Percentage of total hardwood log volume and value.............33

Table 3.3 - Percentage of volume loss per log by site and harvest function...34

Table 3.4 - Percentage of value loss per log by site and harvest function.......35

Table 3.5 - Percentage of volume loss per log by site and species ................ 36

Table 3.6 - Percentage of value loss per log by site and species ................... 37

Table 3.7 - Percentage of volume loss per log by site and damage type..........38

Table 3.8 - Percentage of value loss per log by site and damage type .............39

Table 3.9 - Percentage of volume loss per log by site and grade................... 40

Table 3.10 - Percentage of value loss per log by site and grade .....................40

Table 3.11 - Hardwood veneer value and degrade value .............................4 4

Table 3.12 - Damage volume by harvesting system....................................43

Table 3.13 - Damage value by harvesting system ......................................43

Table 3.14 - Damage volume by terrain slope ..........................................44

Table 3.15 - Damage value by terrain slope .............................................. 45

Table 3.16 - Damage volume by harvesting function...................................45

Table 3.17 - Damage value by harvesting function.....................................46

Table 3.18 - Damage volume by species................................................4 47

Table 3.19 - Damage value by species .................................................... 48

Table 3.20 - Damage volume by damage type ..........................................49

Table 3.21 - Damage value by damage type .............................................50

Table 3.22 - Damage volume by saw log grade .......................................51

Table 3.23 - Damage value by saw $\log$ grade ..........................................51 


\section{LIST OF SYMBOLS / NOMENCLATURE}

1. TPA........................ Trees Per Acre

2. Bd Ft or BF................. Board Feet

3. BC.............................. Black Cherry (Prunus serotina)

4. CO.............................. Chestnut Oak (Quercus prinus)

5. RO............................ Red Oak (Quercus rubra)

6. SM........................... Sugar Maple (Acer saccharrum)

7. WA.......................... White Ash (Fraxinus americana)

8. WO........................... White Oak (Quercus alba)

9. YP............................ Yellow-Poplar (Liriodendron tulipifera)

10. DIFF.......................... Difference

11. GG...................... Grapple Gouge

12. ND....................... No Damage

13. SLB $\ldots \ldots \ldots \ldots \ldots \ldots \ldots \ldots$ Slab

14. SPT $\ldots \ldots \ldots \ldots \ldots \ldots \ldots \ldots$ Split

15. SCP........................ Scrape

16. CKR .......................... Choker

17. FELL....................... Felling

19. SKID ........................ Skidding

20. DECK........................ Decking

21. LOAD .........................Loading 


\section{N T R O D U C T I O N}

The value of forest products from the Appalachian hardwood region continues to grow as the demand for quality hardwood lumber increases. Damage to harvested hardwood logs is becoming a major concern to wood producers in the region, where much of the harvested hardwood timber is turned into veneer, veneer based composites, and sawn into grade hardwood lumber. These trees provide the high quality saw logs and veneer that industry needs for fine furniture, flooring, cabinetry and other wood products (Seymour et al. 1986). The condition of the outer area of the log is important to the potential future grade of the log and the potential value recovered from the $\log$ in the form of veneer or lumber.

Damage to hardwood saw logs can be caused by the felling, skidding, bucking, decking, loading, and unloading stages of the timber harvesting process. Damage was considered to be physical wounds that detracted value from the harvested log. Previous studies have suggested that significant gains can be achieved through a log quality control system. Craig (1982) estimated that implementing a quality control program could increase returns by as much as 50 percent of the harvest value. Murphy and Twaddle (1985) indicated that nearly 40 percent of the standing value of a tree could be lost through degradation during the harvesting process. Williston (1979) also found that breakage and skidding / yarding damage associated with harvest operations destroyed almost six percent of the total value of harvested logs. 
The previous studies have suggested that some damage can be expected, particularly where quality control programs are not emphasized. In addition, most of the studies considered harvest operations where only one or two species of timber were harvested. McNeel and Copithorne (1996) indicated that species was a factor in defining the extent of breakage expected during harvest. They found that more brittle species, in this case western red cedar (Thuja plicata), exhibited significantly more damage than less brittle species in the same harvest.

In Central Appalachia, we can see dozens of species, each with different manufacturing criteria, being harvested off one site. There is m definitive set of criteria for what species are most affected during harvest operations. Nor are there any studies in Appalachian forests that have addressed the question of how harvest operations damage harvested logs.

Since much of the Appalachian Hardwood Region depends on income from quality hardwood products, several questions can be raised concerning the timber harvesting process. How much damage does a hardwood log sustain during felling and the primary/secondary transportation functions of a harvesting operation? Also how does the damage affect the potential value of the hardwood log? During which function does the damage occur? How often does the damage occur to hardwood logs during different functions? The objectives of this thesis are as follows:

(1) To establish which processes cause damage, what kind of damage is caused, where the damage occurs, and how the damage occurs. 
(2) To concentrate on whether the volume and value of hardwood logs harvested in the Appalachian region, are affected by harvest operations.

(3) To determine what actions can be taken to minimize the effects of damage throughout the timber harvesting process. 


\section{H A P T E R 1 - L I T E RA T UR E R E V I E W}

\subsection{Background}

There has been a general trend in the wood products industry to best utilize the raw materials. The factor compelling the industry to do this would seem to be more economical rather than environmental or having to do with public relations. This holds true when taking into account that the underlying goal of all businesses is to maximize profits while minimizing inputs. If harvested logs are severely damaged during one of the many functions of the timber harvesting process, then potential value of the $\log$ is going to be lost. Harvested logs may lose potential value if the bgs are damaged or if improper decisions are made during the different functions of the timber harvesting process.

The value of forest products from the Appalachian Hardwood Region continues to grow as the demand for quality hardwood lumber increases. In addition, there have been substantial increases in demand for veneer type products - specifically laminated veneer lumber (LVL) and parallam (a patented composite product from the TrusJoist MacMillan Company) - from hardwood species such as yellow-poplar (Liriodendron tulipifera) and soft maple (Acer rubrum) (Harlow et al. 1996). Where raw material and final product value are high, as is the case with many hardwood logs, the companies that require these $\operatorname{logs}$ as raw material for mill production have an expectation of quality in the raw material. Quality, in this case, is defined, in part, as 
accurate product dimensions for secondary manufacturing needs. Thus, the dimensions of a log delivered to a lumber manufacturing facility should meet the minimum specifications of top and bottom end diameter and total length. In addition, the log should be free of any production caused defect that would reduce its value in the lumber manufacturing process.

Past studies suggest that significant gains in potential value can be achieved through a log quality control system. Craig (1982) estimated that implementing a quality control program could increase returns by as much as 50-percent of the harvest value. Murphy and Twaddle (1985) indicated that nearly 40-percent of the standing value of a tree could be lost through degradation during the harvesting process. Williston (1979) also found that breakage and skidding / yarding damage associated with harvest operations destroyed almost six percent of the total value of harvested $\log$.

There is no definitive set of criteria for what species are most affected during harvest operations. Nor are there any studies in Appalachian forests that address the question of whether harvest operation produce damage in harvested logs. The previous studies suggest that some damage can be expected, particularly where quality control programs are not emphasized. In addition, most of the cited studies have considered harvest operations where only one or two species of timber are harvested. In the Appalachians, we can see dozens of species, each with different manufacturing criteria, being harvested off one site. McNeel and Copithorne (1996) stated that species is a factor in defining the extent of breakage expected during harvest. This study found that more brittle species, in this case western red cedar (Thuja plicata), 
exhibited significantly more damage than less brittle species in the same harvest (Harlow et al 1996).

Damage to harvested trees or logs can occur in the felling, bucking, extraction (skidding), decking, loading, and hauling functions of the timber harvesting process. Damage, for this study, can be considered anything that detracts value from the harvested $\log$ or tree. This can include physical wounds to the logs caused by any of the harvesting phases, as well as excessive or insufficient trim or any other improper decision made during the log bucking process.

It is important to understand what kind of damage is caused by the different functions of the timber harvesting process. It is also important to understand to what extent harvested logs can be damaged by the harvesting function and system. Understanding what kind of damage, where the damage occurs during the timber harvesting process, and how serious the log is damaged can help the wood products industry make the proper decisions and take the necessary precautions to promote better utilization of forest resources. This, in turn, can help the wood products industry get the maximum value out of each harvested tree or log (Visser et al. 2001).

Damage may not affect the value of harvested logs that are going to be sold to a paper mill, oriented strand board (OSB) plant, or to other wood composite facilities. Damage will, however, affect the potential value of logs that are going to be sold as veneer $\operatorname{logs}$ and saw $\operatorname{logs}$ to a sawmill, or peeler logs going to a wood composite facility. This is especially true when dealing with manufacturing grade hardwood lumber. 
Damage to harvested hardwood logs is especially important in the Appalachian hardwood forest region, where much of the hardwood timber harvested is turned into veneer, or veneer based composites, or is sawn into grade hardwood lumber. The length of each $\log$, as well as the condition of the outer area of the log is important to the potential future grade of the log and the potential value recovered from the $\log$ in the form of veneer or lumber.

\subsection{Log Damage During Felling}

Damage to the harvested butt log of a tree is the area that has received some due attention. Most of the butt log damage occurs during the felling phase, and most of the studies done on butt log damage due to felling have focused on feller-bunchers with shear felling heads. Greene and McNeel (1989) found that shear felling heads left lower stumps in the woods, but the average stump height for a shear felling head was only an inch lower that the average stump height for a feller-buncher equipped with a saw head.

Studies suggest that feller-bunchers in general are safer to operate that the manual use of a chainsaw. Greene and McNeel (1989) indicated that small fellerbunchers with saw heads could be up to 35-percent more productive than shears. Along with being more productive, feller-bunchers equipped with saw heads had next to no effect on damaging the quality of the butt log (Faust and Greene 1989). 
There are several factors that are blamed for shear damage to harvested trees. These factors include the type of shear, the operating condition of the shear, the operating condition of the shear's carrier system, the operator's ability, and tree size (Gallagher et al. 1985). Also, there are three types of damage that can be caused by the use of shears. These damage types include butt shatter, splits, and stump-pull (Shaffer et al. 1990). Stump-pull is directly related to the size of the tree being harvested (Greene and McNeel 1987). This means that as tree size increases, the chances of damaging the butt $\log$ with a shear also increases. Most shear damage could be eliminated through proper equipment maintenance and correct operator technique (Gallagher et al. 1985).

Most shear damage was found in the first twelve inches of the butt $\log$ (Faust and Greene 1989), and it was also found that shear damage became worse after the log was sawn into lumber and dried (Shaffer et al. 1990). The limiting factor in the use of shears as a felling tool is that nearly every butt log will have some extent of shatter present.

In most instances shatter may be removed with the allowance of approximately six inches of trim (Shaffer et al. 1990). Although butt shatter can be removed, it still causes each log to lose a certain measure of value when any amount of trim is cut off. Faust and Greene (1989) also found that shatter was barely noticeable when the log or lumber was green, but was very easy to spot upon drying. Compared to the other damages caused by shears such as splits and stump-pull, shatter is the most detrimental to butt log quality (McNeel and Czerepinski 1987). Faust and 
Greene (1989) also indicated that lumber sawn out of a butt log with shatter could lose up to 42-percent of its tensile strength near the butt end.

Damage to logs harvested with feller-bunchers equipped with shears is costly. Volume losses of up to 4.5-percent were typical when using shears, while losses of only 0.25 -percent were found when operating with a saw head (Greene and McNeel 1989). The total value losses from shear damaged logs is upwards of 13-percent (Middleton and Munroe 1987). The use of saw heads can be justified by the loss of value experienced when using feller-buncher equipped with shears.

Chainsaw felling damage compared to damage caused by felling with a fellerbuncher equipped with a shear head is negligible. Chainsaw felling damage to the butt $\log$ was found to be 0.64-percent of the volume (Gallagher et al. 1985). To put it in perspective, approximately 1 out of every 150 trees felled with a chainsaw will sustain butt log damage. Also, feller-bunchers equipped with bar saws may have an advantage over chainsaw felling in the hardwood forests of the Appalachians where the majority of the harvests are partial removals (Hassler et al. 1999). Feller-bunchers have the ability to lay the fallen tree stem on the ground without damaging the upper logs of surrounding trees. Chainsaw fallers many times damage the upper logs of the fallen tree stem and the residual trees in the stand as well (Lamson et al. 1985). 


\subsection{Log Damage During Bucking}

While little or no physical damage occurs to the harvested logs during the bucking stage, potential value can be lost in a single bucking cut. In the Appalachian hardwood forest region, the concept of an optimal bucking process is logical, especially when many of the logs harvested in this region will be broken down into hardwood lumber. Correct log bucking procedures can potentially increase the yield from each tree harvested. This can increase profits for the logger and the sawmill. Improper bucking may not damage the log in a physical sense, but it can damage the potential value gained from bucking correctly (Zavala 1995, Pickens et al. 1992, Sessions 1988).

The root of the problem dealing with improper bucking is the log bucker himself. The bucker is the link between a felled tree and the potential value recovered from that tree. Seven different major causes of poor bucking practices were recognized in bucking Northern hardwoods (Pickens et al. 1992). These causes include the complexity of bucking specifications, unquantified or imprecise specifications, number of log grades, production pressure, lack of incentives, lack of training, and the lack of decision aids. All of these causes seem to be viable means of poor bucking decisions, but three of them, lack of training, lack of incentives, and lack of proper decision making aids, stand out above the rest.

Once the tree is bucked improperly, a recovery of the potential value lost due to the misplaced cut is not possible (Sessions 1988). One study found that excessive trim allowed by the bucker accounted for over 4-percent of the mill's total input log 
volume (Zavala 1995). Improper bucking could lead up to almost a 25-percent loss in potential log value for certain operations (Sessions 1988). Improper bucking can definitely be a serious problem when it comes to volume and value recovery from harvested trees.

There are several ways to deal with the problem of improper bucking. The bucking operation can be saved until the tree gets to the mill (Pickens et al. 1992, Sessions 1988). A gain of 39 to 55 percent in gross value can be obtained if logs were bucked at the mill rather than bucking them at the logging operation site. Another option is to utilize a team of highly trained / highly skilled buckers (Pickens et al. 1992). The team of skilled buckers would be mobile and move from operation to operation. This might be impractical. Some of the potential value gained by using this highly skilled team would be lost to increased training costs and downtime between travel to different operations. However, the potential of training should not be overlooked as a tool to improve bucking performance.

Suppose that when a log is optimally bucked, it increases the potential value of the log that the log bucker never sees. Maybe the largest problem was motivating the bucker to improve his potential value recovery (Pickens et al. 1992). A Computer Aided Bucking Decisions (CABD) program could be used for dealing with improper bucking decisions in the woods (Sessions 1988). The program is designed to optimize log volume and value recovery and allows the log bucker to optimize tree value in the woods as soon as it is felled. There is no need to transport full-length trees to the mill or worry about improperly bucking the trees that are too large to haul. Sessions (1988) also showed that gains of up to 10-percent in total tree value could be obtained 
by using such a program. By optimizing volume recovery in the woods using these practices, the volume can be saved and used to increase profit (Zavala 1995).

\subsection{Log Damage During Extraction, Decking, Loading, and Hauling}

There are many different ways for trees or logs to be extracted during the timber harvesting process. These include conventional ground-based systems utilizing either cable or grapple skidders or bulldozers, forwarders, shovel logging, or other systems such as cable yarding or helicopter logging. Ground-based extraction by rubber-tired skidders or tracked carriers is the most common method found in the Appalachian hardwood forest region (Egan 1999). The problem with these methods is that they skid the full-length trees or logs by dragging them across the ground. Dragging the logs over the ground could present some type of potential damage to the harvested logs. Also, skidding full-length trees during partial harvests can contribute to log breakage in certain situations, such as when skidding through switchbacks.

Harvested logs are decked at the landing before they are loaded. Skidders or dozers can deck logs, or a loader can deck them. Potentially, harvested logs might be damaged during the decking process. Harvested logs may be pushed into each other by a skidder and damaged in different ways. Logs might sustain damage from the grapple of a knuckleboom-loader by pinching or puncturing the logs rather than grabbing them whole. 
In most cases harvested logs are loaded onto trucks at the landing. In Central Appalachia, a knuckleboom-loader with a type of grapple head attachment usually loads logs. No previous studies were found dealing with damage caused by loading to harvested logs. Potential damage might include grapple pinches, gouges, and breakage caused by lifting harvested logs incorrectly.

After harvested logs are loaded onto a truck at the landing, the logs are hauled to a secondary processing facility. The potential for damage during the hauling process is limited, yet some does occur. Harvested logs could be potentially damaged during hauling by pinches and any breakage caused by binding down the logs to the truck. Although in this area, potential for damage seems limited, value could be lost during this timber harvesting function.

No previous studies were found exclusively dealing with damage occurring to harvested logs caused by different extraction methods. Research on damage caused by decking, loading, and hauling is also very limited. There is little certainty that damage can or does occur to harvested logs during theses harvesting processes. It would be beneficial to discover the extent of damage caused to harvested logs during extraction, decking, loading, and hauling in Central Appalachia. It would also be valuable to determine the value loss associated with the damage to hardwood saw logs. 


\subsection{Summary}

The Appalachian hardwood forest region is ble ssed with yielding large quantities of quality hardwood timber. Quality hardwoods usually bring a superior profit when being sawn into hardwood lumber or sliced or peeled for veneer. Potential value of harvested logs can be decreased by the amount of damage associated with them. If little damage occurs, then more potential value can be recovered from harvested trees. The problems associated with damages to harvested logs can be summarized as follows:

(1) Both harvest and site factors influence the harvested log damage to some extent (Cline et al. 1991).

(2) Damage to harvested logs and trees can be caused by six different stages of harvesting: felling, bucking, extraction, decking, loading and hauling. Of those six phases, most of the information can be found from previous studies that dealt with damage to harvested trees and logs due to the felling, bucking, and extraction processes. The damages occurring in theses three phases are usually severe compared to the damage due to decking, loading, and hauling.

(3) Previous studies mostly focus on value lost to harvested trees caused by the felling and bucking processes. In the Appalachian hardwood forest region, felling is mostly done manually by the use of chainsaws, which allows for minimal control over directional felling. 
(4) Some damage to harvested trees and logs may always exist to some extent. The point is, however, how to minimize such damages. By minimizing the intensity as to which damage happens, potential value recovery can be maximized. 


\section{CHA P T E 2 - METHODS \& DATA COLLECTION}

\subsection{Methods}

Two harvesting systems and the amount of harvesting damage that was sustained during six harvesting functions of felling, skidding, bucking, decking, loading, and hauling were examined on four different sites. The chainsaw felling and cable skidding is referred to as the manual harvesting systems, which were operated on two sites. The feller-buncher and grapple skidding is referred to as the mechanized harvesting systems, and were evaluated on the other two sites (Table 2.1). Field observations along with a questionnaire sent to industry were used to collect the data for the project. Harvested log damage was difficult to measure efficiently in the field, yet it was accomplished successfully and safely with the logger's productivity in mind.

Commercially important hardwood logs from each harvesting site were observed for any damage sustained from the harvesting operations. Observations were made for each of the four harvesting functions that could be measured on site: felling, skidding, decking, and loading. The bucking and hauling functions were looked at by way of a questionnaire sent to various hardwood sawmillers and loggers in the Appalachian hardwood forest region. 
Table 2.1 - Harvest equipment spread.

\begin{tabular}{|c|c|c|c|c|}
\hline & Site 1 & Site 2 & Site 3 & Site 4 \\
\hline Felling & $\begin{array}{c}\text { Timbco 425-D } \\
\text { Hydro-Buncher } \\
\text { w/ bar saw }\end{array}$ & $\begin{array}{l}\text { Husqvarna } \\
\text { 385XP }\end{array}$ & $\begin{array}{l}\text { Husqvarna } \\
\text { 372XP }\end{array}$ & $\begin{array}{c}\text { Timbco 455-C } \\
\text { Hydro buncher } \\
\text { w/bar saw }\end{array}$ \\
\hline Skidding & $\begin{array}{l}\text { Timberjack 660C } \\
\text { Grapple Skidder }\end{array}$ & $\begin{array}{c}\text { Timberjack 380C } \\
\text { Cable Skidder }\end{array}$ & $\begin{array}{c}\text { John Deere 540B } \\
\text { Cable Skidder }\end{array}$ & $\begin{array}{l}\text { Timberjack } 460 \\
\text { Grapple Skidder }\end{array}$ \\
\hline $\begin{array}{l}\text { Decking/ } \\
\text { Loading }\end{array}$ & $\begin{array}{l}\text { Prentice } 310 \mathrm{E} \\
\text { knuckleboom }\end{array}$ & $\begin{array}{c}\text { Timberjack } 330 \\
\text { knuckleboom }\end{array}$ & $\begin{array}{l}\text { Husky Brute } \\
\text { XL-175 } \\
\text { knuckleboom }\end{array}$ & $\begin{array}{c}\text { Timberjack } 330 \\
\text { knuckleboom }\end{array}$ \\
\hline Other & $\begin{array}{l}\text { Caterpillar } 517 \\
\text { w/ swing boom }\end{array}$ & & & \\
\hline
\end{tabular}




\subsection{Site Information}

Harvest sites were all found in the north-central area of West Virginia in Preston, Monongalia, and Marion counties (Figure 2.1), and were chosen based on the species composition, average slope, and stand conditions (Table 2.2). The average slope was an important factor in choosing the harvest sites because similarity was needed for a functional design. Two different average slopes, 5-percent and 25-percent, were chosen for the project in order to determine the effect terrain-slope had on hardwood log damage. One mechanized harvesting site and one manual harvesting site was chosen for each of the two slope treatments.

Site information includes the site name, site slope in percent, site aspect in degrees, harvest type, tract size in acres, stand density, and harvest intensity. Operator experience in years was also recorded for each of the four site oriented harvesting functions. 


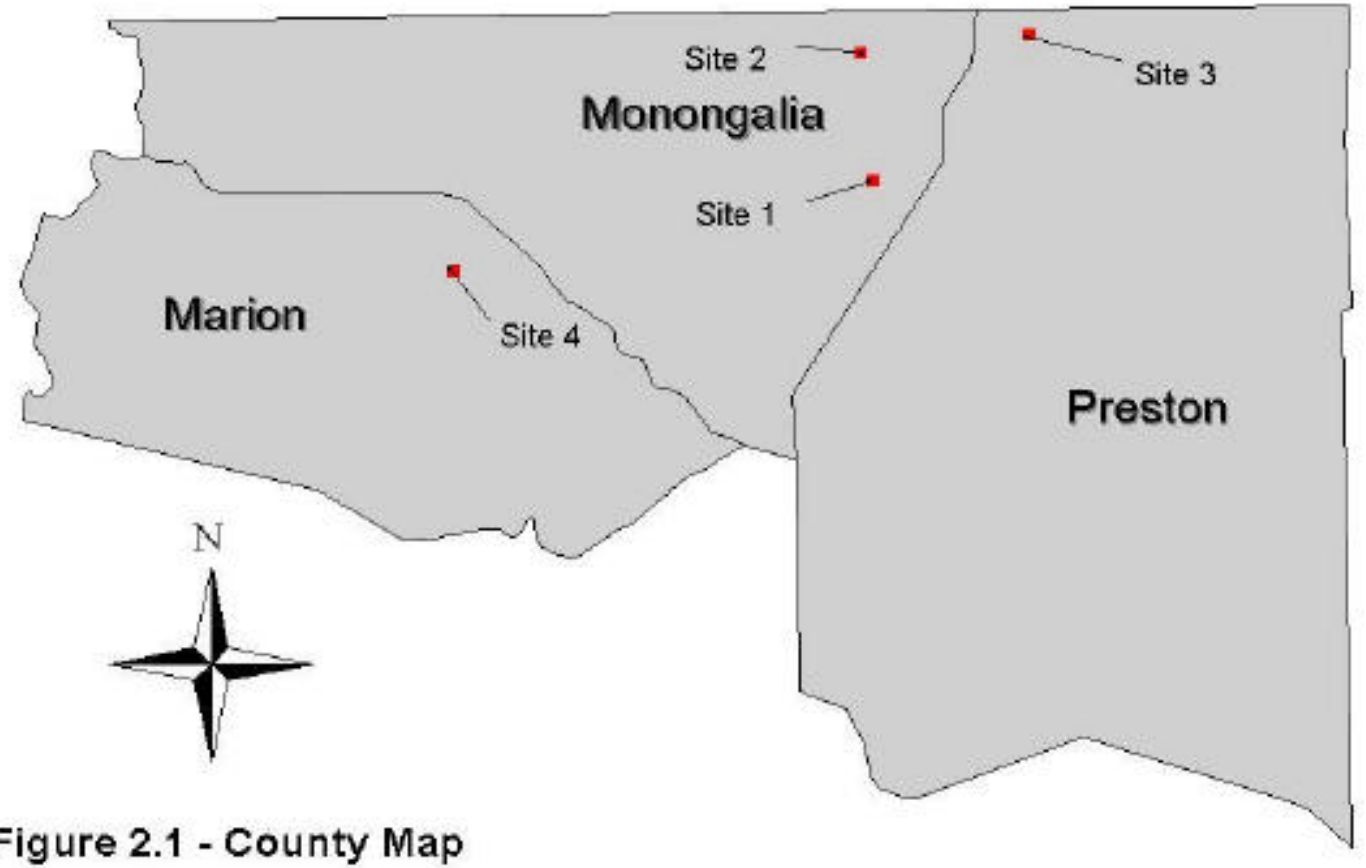


Table 2.2 - Site conditions.

Site 1

\begin{tabular}{|c|c|c|c|c|}
\hline & Site 1 & Site 2 & Site 3 & Site 4 \\
\hline Harvest Method & Mechanized & Manual & Manual & Mechanized \\
\hline Harvest Type & Partial Cut & Partial Cut & Partial Cut & Partial Cut \\
\hline Terrain Slope (\%) & $5-10 \%$ & $5-15 \%$ & $20-25 \%$ & $15-25 \%$ \\
\hline Aspect & N-NW & $\mathrm{N}-\mathrm{NE}$ & NE & NW \\
\hline Total logs sampled & 1000 & 1000 & 1000 & 1000 \\
\hline Time of harvest & Fall & Fall & Spring & Spring \\
\hline Tract Size (acres) & 100 & 75 & 80 & 125 \\
\hline Stand Density (tpa) & 115 & 105 & 125 & 117 \\
\hline Residual Density (tpa) & 40 & 65 & 90 & 45 \\
\hline Species Composition & $\begin{array}{c}\text { Mixed } \\
\text { Hardwoods }\end{array}$ & $\begin{array}{c}\text { Mixed } \\
\text { Hardwoods }\end{array}$ & $\begin{array}{c}\text { Mixed } \\
\text { Hardwoods }\end{array}$ & $\begin{array}{c}\text { Mixed } \\
\text { Hardwoods }\end{array}$ \\
\hline $\begin{array}{c}\text { Average Merchantable } \\
\text { Height (ft) }\end{array}$ & 29.3 & 34.2 & 32.7 & 30.7 \\
\hline $\begin{array}{l}\text { Average Tree } \\
\text { Diameter (in) }\end{array}$ & 15.6 & 17.5 & 16.3 & 16.1 \\
\hline Faller Experience (yrs) & 4 & 12 & 7 & 3 \\
\hline $\begin{array}{c}\text { Skidder } \\
\text { Experience }(\mathrm{yrs})\end{array}$ & 23 & 39 & 25 & 5 \\
\hline $\begin{array}{c}\text { Loader } \\
\text { Experience }(\mathrm{yrs})\end{array}$ & 25 & 1 & 4 & 20 \\
\hline
\end{tabular}


The four harvesting sites had similar species composition and stand densities. The more dominant species sampled were red oak (Quercus rubra), white oak (Quercus alba), chestnut oak (Quercus prinus), black cherry (Prunus serotina), red maple (Acer rubrum), sugar maple (Acer sacharrum), and yellow-poplar (Liriodendron tulipifera) (Harlow et al. 1996). Overall species composition from sampled logs can be found in Table 2.3. Average stand density for the four tracts was approximately 115 trees per acre. Overall, the four harvest sites were very similar, with the exception of average slope.

\begin{tabular}{ccccc}
\hline \multicolumn{5}{c}{ Table 2.3 - Site species composition (Number of logs sampled) by site. } \\
\hline Species & Site 1 & Site 2 & Site 3 & Site 4 \\
\hline Black cherry & 24 & 265 & 107 & 59 \\
Chestnut oak & 290 & 16 & 37 & 4 \\
Red oak & 245 & 212 & 269 & 222 \\
Sugar maple & 160 & 80 & 17 & 267 \\
White ash & 36 & 86 & 11 & 11 \\
White oak & 51 & 34 & 15 & 62 \\
Yellow-poplar & 194 & 307 & 544 & 375 \\
\hline
\end{tabular}




\subsection{Data Collection}

One thousand commercially important hardwood logs from each of the four harvesting sites were observed for measurable damage sustained during the harvesting operation. Of the 1000 observations per harvesting site, 250 observations were made for each of the four harvesting functions that could be measured on site: felling, skidding, decking, and loading. A total of 4000 observations were conducted in the field.

Overall, the sample size for each of the harvest sites were equal with 1000 observations per site. Also, the sample size for each of the harvesting functions within each site were equal with 250 observations per harvesting function per harvest site. Sample sizes for species, damage type, and log grade were not equal.

Data collected for each observed log contain the following recorded information: large end diameter, small end diameter, length, species, damage type, damage location, damage dimension, log grade, and comments. Large end diameter and small end diameter were measured in inches within two-inch diameter classes (Shiver and Borders 1996). Length of each saw log was measured in feet.

Species was recorded as a two-letter code. Only commercially important species were recorded, which consists of red oak (Quercus rubra), white oak (Quercus alba), chestnut oak (Quercus prinus), sugar maple (Acer saccharum), white ash (Fraxinus americana), black cherry (Prunus serotina), and yellow-poplar (Liriodendron tulipifera) (Harlow et al. 1996).

Damage type was recorded as the type of damage, if any, the observed log sustained. There were five types of damage recorded: 
(SPT) Split damage - damage that occurred from any of the harvesting functions that resulted in a portion of the log being split in two yet still attached to the main stem (Figures $2.2 \& 2.3$ ).

(GG) Gouge damage - damage that occurred from grapple tongs from log loaders or grapple skidders, or damage occurring from chokers used on cable skidders (Figures $2.4 \& 2.5$ ).

(SLB) Slab damage - damage that occurred from any of the harvesting functions that resulted in a portion of the log being split from the main stem and discarded (Figures $2.6 \& 2.7$ ).

(SCP) Scrape damage - damage to the log that occurred during any of the harvesting functions that resulted in a portion of the log being scraped away (Figures 2.8 $\& 2.9)$.

(ND) No damage - log sustained no damage during the observation period (Figures $2.10 \& 2.11)$. 


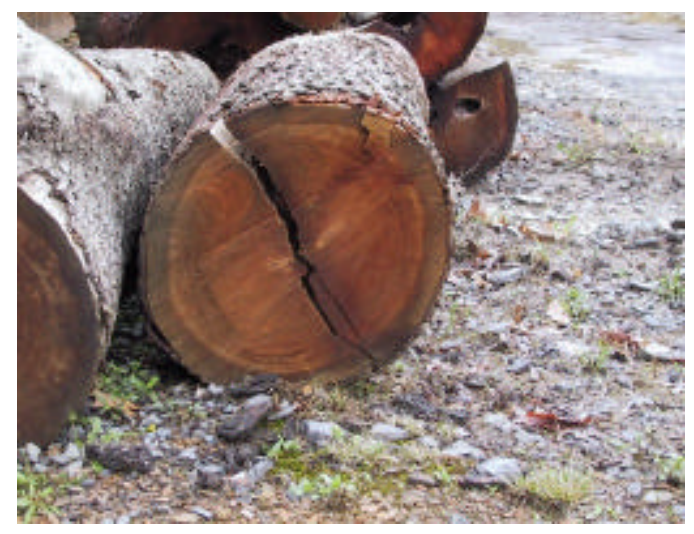

Figure 2.2 - Log length split in cherry log

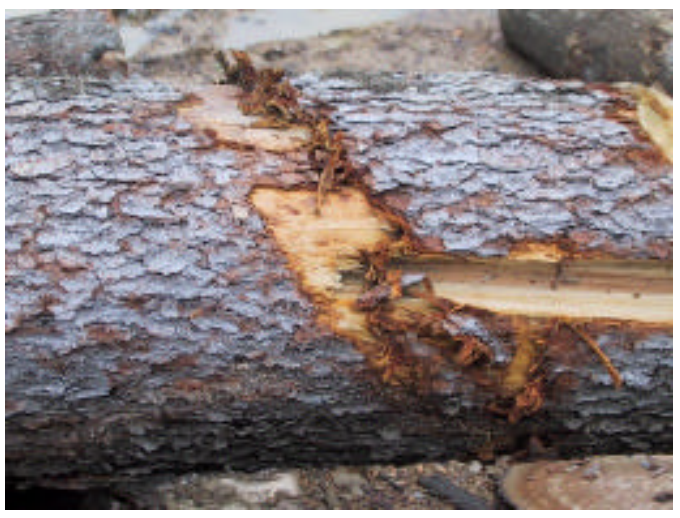

Figure 2.4 - Choker gouge on cherry log

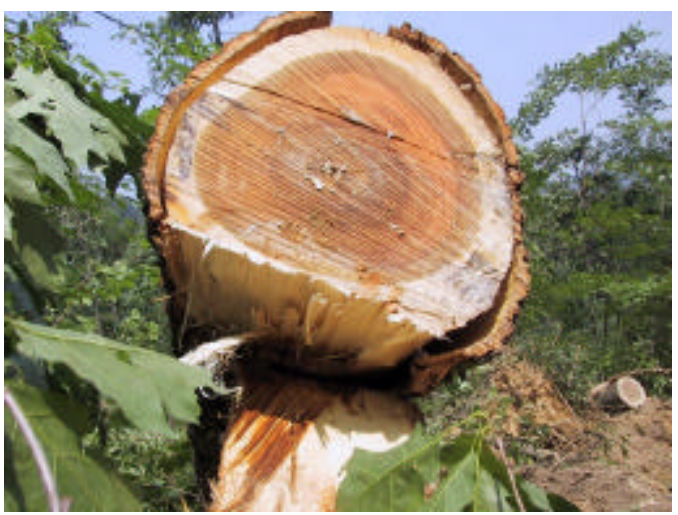

Figure 2.6 - Butt slab on cherry log caused by felling

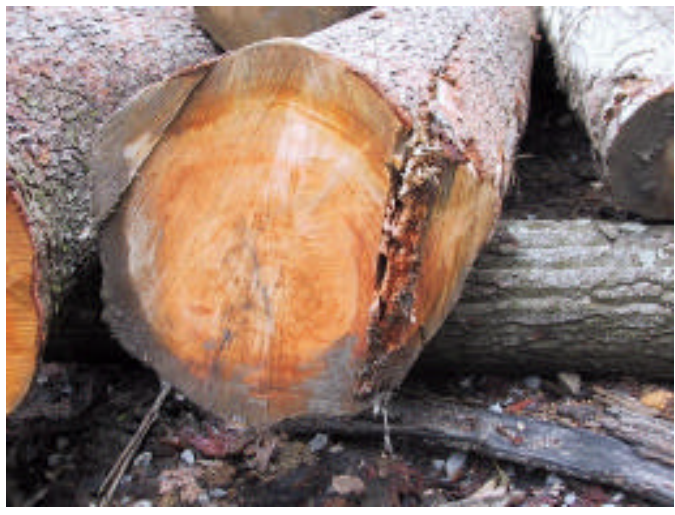

Figure 2.3 - Butt split in cherry log

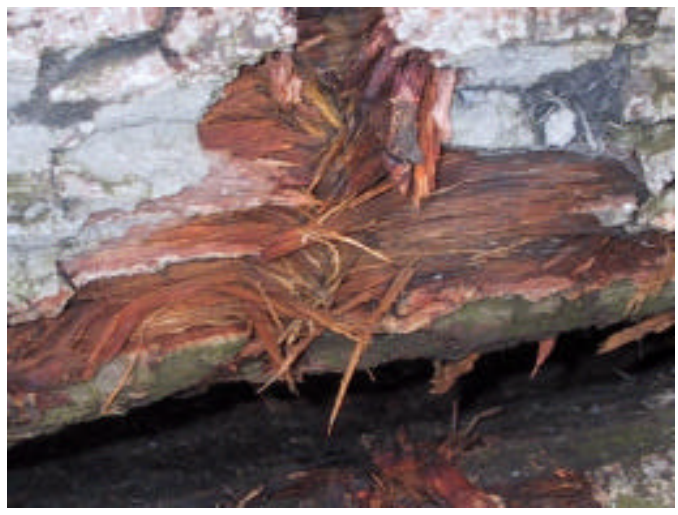

Figure 2.5 - Grapple tong gouge on red oak log

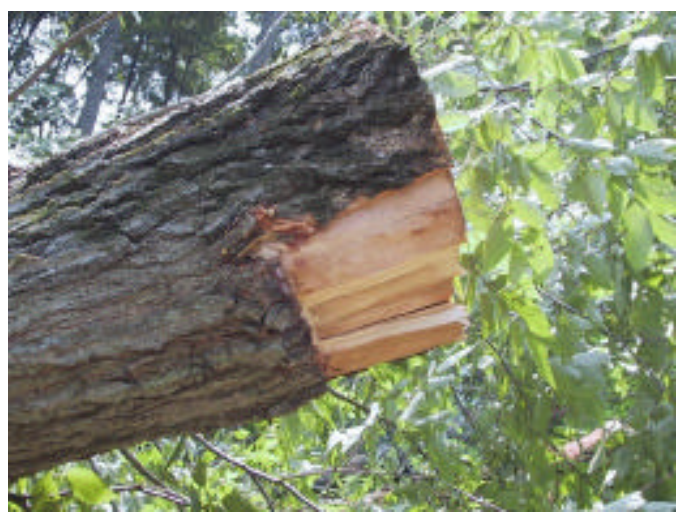

Figure 2.7 - Butt slab on red oak log caused by felling 


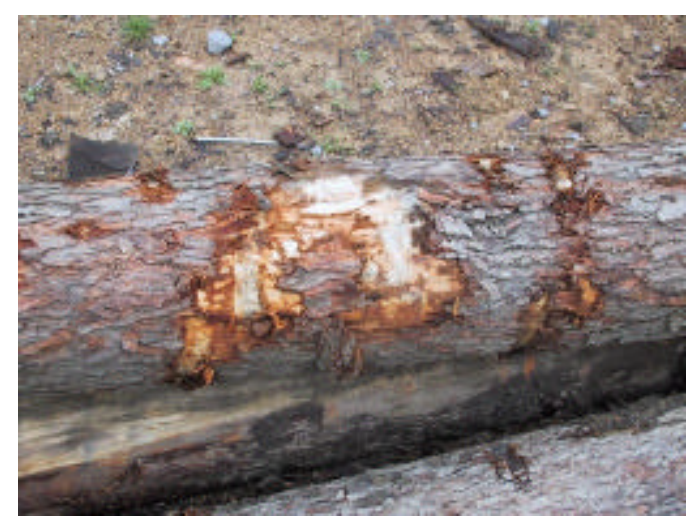

Figure 2.8 - Scrape on cherry log caused by skidding

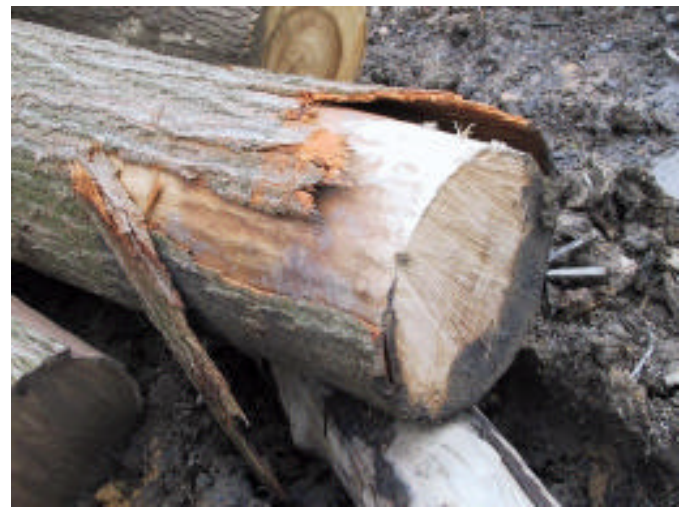

Figure 2.10 - No woody tissue damage

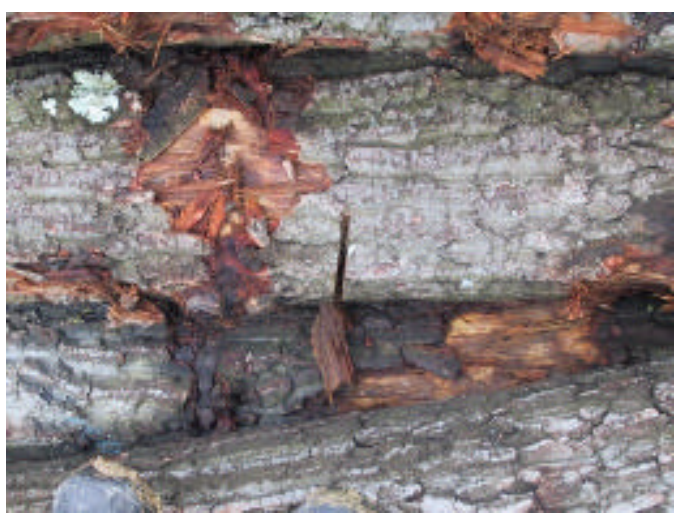

Figure $2.9-$ Scrape on chestnut oak caused by skidding

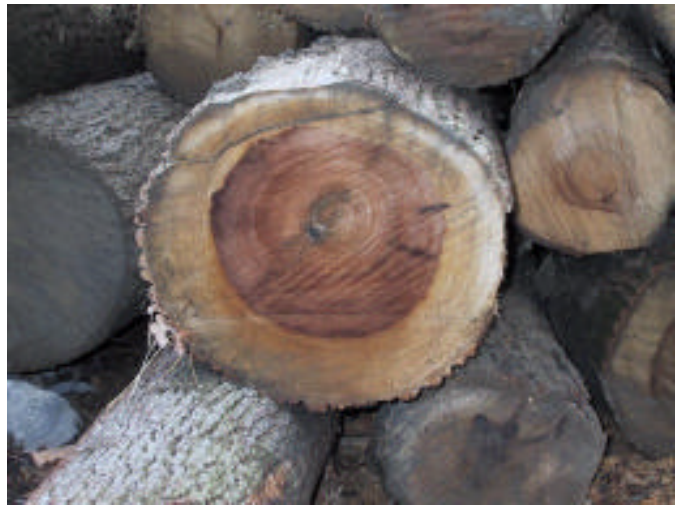

Figure 2.11 - Frost crack in yellow-poplar log

Damage location was defined as the general area where the damage occurred, which are the bottom (large end), middle, and the top (small end) of the log. Damage dimension was a volumetric measureme nt of the damaged area. The damaged area was calculated by measuring length, width, and depth of damage at the greatest point in inches. This method overestimates the amount of damage sustained by each log, but was necessary in order to make the measurements efficiently. The grade of each log was based on the log's dimensions and the visual defects found on the log (Hanks et al. 
1980, Carpenter et al. 1989). The grades ranged from a grade one (high quality) to a grade three (low quality) (Hanks 1976). The comments section of the data collection sheet was used as an indication of the severity of the damaged area.

As mentioned earlier, harvested log damage cannot be easily measured efficiently in the field. Felling damage was recorded by observing the felling process at a safe distance. After the trees had been successfully felled and the area was clear of immediate danger, harvested logs and their attributes were observed and recorded, along with any damage the logs may have sustained.

Skidding damage was recorded by observing the skidding function from a safe distance, as the logs were brought to the landing. After the logs reached the landing and were clear of the skidder, the logs and their attributes were observed and recorded, along with any damage that may have been sustained during the skidding function of the harvesting process.

The bucking function of the timber harvesting process is an important function that usually causes the greatest damage and value loss. Improper bucking may not damage the log in a physical sense, but it can damage the potential value gained from bucking to the correct dimensions (Zavala 1995, Pickens et al. 1992, Sessions 1988). The bucking function was not included along with other harvest field observations of the felling, skidding, decking, and loading functions in this project because it is attributed mostly to improper decision making (Pickens et al. 1992), and does not contribute any real physical damage to harvested logs. The bucking function of the timber harvesting process was, however, addressed in the questionnaire utilized in this project. 
The decking function was observed from a safe location on the landing. The log decking damage was recorded by observing logs at the landing after they were decked or while they were being sorted.

Loading damage was recorded by observing the loading function from a safe position on the landing. After the log truck had been loaded, observations were made and measurements were recorded along with any damage the logs may have sustained during the loading function of the timber harvesting process.

In addition to a field study, a questionnaire was constructed dealing with harvested hardwood log damage and sent to various wood product manufacturers and logging companies located in the Appalachian hardwood forest region. This questionnaire was used to get an idea as to how industry felt about the impact harvesting damage has on $\log$ value. The questionnaire was also used to determine the importance of the six harvesting functions, including the bucking and hauling functions, and how they related to damage and value loss. 


\section{CHA P T E 3 - DA TA A NALYSISAND RESULTS}

\subsection{Data Analysis}

A total of four treatments were designed for the data collection: (1) mechanized felling and grapple skidding on 5-percent average terrain slope, (2) mechanized felling and grapple skidding on 25-percent average terrain slope, (3) manual felling and cable skidding on 5-percent average terrain slope, and (4) manual felling and cable skidding on 25-percent average terrain slope. Each treatment has four fields: (1) felling, (2) skidding, (3) decking/sorting, and (4) loading. This block design allowed comparison of the means of the independent variables such as damage volume found for the four harvesting function fields among the four harvesting system/terrain slope treatments (Dowdy and Wearden 1991).

Value loss was the major concern in data analysis. Saw log damage was viewed in terms of log volume loss. In order to give each log in the data set a pre-and postdamage monetary value, a system was developed based on answers to questionnaires received from the hardwood lumber industry, and current saw log market prices.

Pre-damage log grades were given to all logs based on their dimensions and superficial condition. Log volumes were converted from a cubic foot volume to a Doyle board foot volume based on the equation (Avery and Burkhart 1994):

$$
\mathrm{Bd} \mathrm{ft}=[(\mathrm{D}-4) / 4]^{2} \mathrm{~L}
$$


Where $\mathrm{D}$ is the $\log$ diameter in inches and $\mathrm{L}$ is the log length in feet. Also, a monetary value was assigned to the log based on Doyle board-foot scale, species, and current hardwood saw log market prices (Finley 2002). This system then assigned a post-damage volume loss in board feet (Doyle Scale) and monetary value to each log based on the amount of damage the log had sustained (Wenger 1984). Each log then had a pre-damage and a post-damage monetary value associated with it. Value loss was determined by calculating the difference between the pre-damage value and the post-damage value.

Value loss was also applied to a data set of veneer logs. The veneer data set was randomly selected from the entire data set, and consisted of the species black cherry, red oak, sugar maple, white ash, and white oak. The logs were randomly selected from each species and grade class. A total of 175 (4.4-percent of the total number of observed saw logs) veneer logs were selected to analyze value loss in veneer logs (Rast et al. 1971).

Veneer log damage was viewed in terms of log degrade. A monetary value was given to each veneer log based on log scale (Doyle board feet), species, and current hardwood veneer market prices. It was then assumed that each veneer log had sustained woody tissue damage, such as a large split or slab, and could not meet veneer log grade standards. Each log was then assigned a new grade based on its dimension, and a new monetary value was also given to it based on its scale, species, and current hardwood saw log market prices. Each log then had a veneer value and a degrade (saw log grade) monetary value associated with it. Value loss was determined 
by calculating the difference between the veneer value and the degrade (saw log) value.

Data was analyzed by using Statistical Analysis Systems (SAS). The general linear model (GLM) procedure, which is a type of analysis of variance (ANOVA), was used to determine if any significant differences existed among harvesting systems, slope classes, harvesting functions, species, damage types, or log grades. Four harvest sites (terrain slope and harvesting system), four harvest functions, seven species, five damage types, and three log grades were examined and measured as the independent variables for this statistical analysis.

The dependent variables were damage volume and value loss. These variables were tested with Duncan's New Multiple Range Test (DNMRT) at the 5-percent level to determine if there were any significant differences between the six independent variable classes. DNMRT was chosen over Fisher's Least Significant Difference (FLSD) procedure for two reasons. FLSD requires that the null hypothesis be rejected in the ANOVA procedure, and DNMRT is slightly more conservative than FLSD (Dowdy and Weardon 1991).

A questionnaire was also sent out to hardwood sawmills in the Appalachian forest region. The questionnaire asked professionals basic questions about hardwood log damage caused by timber harvesting. Topics addressed the following areas: hauling logs to the mill, damage caused by harvesting functions, damage types, volume and value loss, guidelines or training capable of dealing with damage, and efforts to minimize damage to hardwood saw logs 


\subsection{Results}

The volume loss associated with commercially important saw logs caused by timber harvesting damage was evaluated by calculating the total volume of saw logs as well as a total post-damage volume of saw logs. Correspondingly, the total value of logs before and after damage was also calculated.

Veneer logs were analyzed for value loss based on degrade from a veneer log to a grade saw log. Total value of veneer quality logs and logs degraded to saw log quality were calculated and value loss was established. These results are then categorized by species and saw log grade. Along with the focus on overall value and volume loss, differences between manual and mechanical harvesting systems and among the harvesting functions were also examined.

\subsubsection{Saw Log Volume and Value Loss}

Volumes for saw logs were calculated using the Doyle log rule and values was based on current saw log market prices (Table 3.1). Log values are determined by their species and grade. Log grades are based on dimension and superficial condition. Log grades used are grades 1 through 3, with grade 1 being the highest quality, and grade 3 being the lowest quality. 


\section{Table 3.1 - Hardwood log prices ${ }^{1}(\$)$}

\begin{tabular}{|c|c|c|c|c|}
\hline Species & $\begin{array}{c}\text { Grade } \\
\mathbf{3} \\
\end{array}$ & $\begin{array}{c}\text { Grade } \\
\mathbf{2} \\
\end{array}$ & $\begin{array}{c}\text { Grade } \\
1\end{array}$ & $\begin{array}{c}\text { Veneer } \\
\text { Avg. }\end{array}$ \\
\hline Northern Red Oak & $\$ 146$ & $\$ 406$ & $\$ 501$ & $\$ 916$ \\
\hline White Oak & $\$ 103$ & $\$ 212$ & $\$ 291$ & $\$ 1,065$ \\
\hline Mixed Oak & $\$ 77$ & $\$ 124$ & $\$ 177$ & $\$ 0$ \\
\hline Black Cherry & $\$ 211$ & $\$ 582$ & $\$ 813$ & $\$ 2,177$ \\
\hline White Ash & $\$ 90$ & $\$ 162$ & $\$ 269$ & $\$ 1,003$ \\
\hline Hard Maple & $\$ 196$ & $\$ 415$ & $\$ 876$ & $\$ 1,298$ \\
\hline Yellow Poplar & $\$ 90$ & $\$ 162$ & $\$ 239$ & $\$ 0$ \\
\hline
\end{tabular}

A comparison of volume and value is provided in Table 3.2 illustrating the effect all logging functions have on total value by species and grade. Volume loss and value loss for saw logs are shown as percentages of the total observed logs. Also, volume loss and value loss are shown as percentages of the total damaged saw logs. 
Table 3.2 - Percentage of total hardwood log volume and value loss.

\begin{tabular}{|c|c|c|c|c|}
\hline & $\begin{array}{l}\text { Volume Loss } \\
\text { per Log (BF) }\end{array}$ & $\begin{array}{c}\text { Volume Loss per } \\
\text { Damaged Log (BF) }\end{array}$ & $\begin{array}{l}\text { Value Loss } \\
\text { per Log }(\$)\end{array}$ & $\begin{array}{c}\text { Value Loss per } \\
\text { Damaged Log (\$) }\end{array}$ \\
\hline \multicolumn{5}{|c|}{ 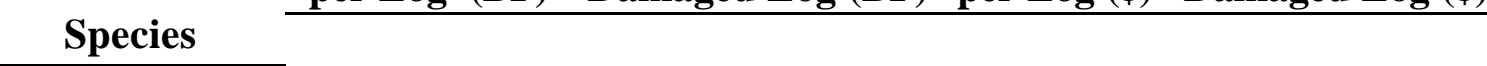 } \\
\hline Yellow-Poplar & 0.15 & 2.50 & 0.12 & 2.20 \\
\hline Red Oak & 0.08 & 1.30 & 0.08 & 1.30 \\
\hline Sugar Maple & 0.14 & 1.50 & 0.14 & 1.40 \\
\hline Black Cherry & 0.13 & 3.30 & 0.13 & 3.10 \\
\hline Chestnut oak & 0.04 & 0.70 & 0.03 & 0.60 \\
\hline White Oak & 0.29 & 2.00 & 0.28 & 1.80 \\
\hline White Ash & 1.11 & 15.70 & 1.15 & 15.50 \\
\hline \multicolumn{5}{|l|}{ Site } \\
\hline 1 & 0.02 & 0.70 & 0.03 & 0.60 \\
\hline 2 & 0.23 & 7.90 & 0.15 & 5.70 \\
\hline 3 & 0.23 & 2.90 & 0.20 & 2.50 \\
\hline 4 & 0.12 & 1.00 & 0.14 & 1.10 \\
\hline \multicolumn{5}{|l|}{ Function } \\
\hline Felling & 0.57 & 4.80 & 0.48 & 3.60 \\
\hline Skidding & 0.02 & 0.30 & 0.02 & 0.30 \\
\hline Decking & 0.03 & 0.50 & 0.03 & 0.40 \\
\hline Loading & 0.01 & 0.30 & 0.01 & 0.20 \\
\hline
\end{tabular}




\subsubsection{Volume and Value Loss by Site and Harvesting Function}

Volume loss per log (Table 3.3) suggests that the felling function causes the most damage with an average of 0.57 -percent of the total volume being lost per log. The decking, skidding, and loading functions show less damage volume loss. Decking and skidding functions show damage volume loss averages of 0.03 -percent and 0.02 percent respectively, while the loading function shows the least amount of average volume loss with 0.01 -percent per log.

\begin{tabular}{|c|c|c|c|c|c|c|c|c|c|c|}
\hline & \multicolumn{4}{|c|}{ Observed Logs } & \multicolumn{6}{|c|}{ Damaged Logs } \\
\hline Function & $\begin{array}{c}\text { Site } 1 \\
(\%)\end{array}$ & $\begin{array}{c}\begin{array}{c}\text { Site 2 } \\
(\%)\end{array}\end{array}$ & $\begin{array}{c}\text { Site 3 } \\
(\%)\end{array}$ & $\begin{array}{c}\text { Site } 4 \\
(\%)\end{array}$ & $\begin{array}{c}\text { Total } \\
(\%)\end{array}$ & $\begin{array}{c}\text { Site 1 } \\
(\%)\end{array}$ & $\begin{array}{c}\begin{array}{c}\text { Site 2 } \\
(\%)\end{array}\end{array}$ & $\begin{array}{c}\text { Site } 3 \\
(\%)\end{array}$ & $\begin{array}{c}\text { Site } 4 \\
(\%)\end{array}$ & $\begin{array}{c}\text { Total } \\
(\%)\end{array}$ \\
\hline Fell & 0.05 & 1.01 & 0.83 & 0.44 & 0.57 & 0.69 & 18.50 & 6.30 & 2.00 & 4.75 \\
\hline Skid & 0.01 & $<0.01$ & $<0.01$ & 0.04 & 0.02 & 0.79 & 0.31 & 0.19 & 0.27 & 0.31 \\
\hline Deck & 0.02 & 0.02 & 0.05 & 0.02 & 0.03 & 0.88 & 0.82 & 0.48 & 0.19 & 0.46 \\
\hline Load & 0.01 & 0.01 & $<0.01$ & $<0.01$ & 0.01 & 0.36 & 0.47 & 0.17 & 0.09 & 0.28 \\
\hline Total (\%) & 0.03 & 0.16 & 0.20 & 0.14 & & 0.64 & 5.69 & 2.48 & 1.07 & \\
\hline
\end{tabular}


The percentage of value loss per log by site and harvesting function suggests that the felling function causes the most value loss with an average of 0.48-percent (Table 3.4). The decking function causes the second highest value loss with an average of 0.03 -percent. The skidding and loading functions cause the lowest value loss with 0.02-percent and <0.01-percent respectively.

\begin{tabular}{|c|c|c|c|c|c|c|c|c|c|c|}
\hline & & Observ & d Logs & & & & Dama: & d Logs & & \\
\hline Function & $\begin{array}{c}\text { Site } 1 \\
(\%)\end{array}$ & $\begin{array}{c}\text { Site } 2 \\
(\%)\end{array}$ & $\begin{array}{c}\text { Site } 3 \\
(\%)\end{array}$ & $\begin{array}{c}\text { Site } 4 \\
(\%)\end{array}$ & $\begin{array}{c}\text { Total } \\
(\%)\end{array}$ & $\begin{array}{c}\text { Site } 1 \\
(\%)\end{array}$ & $\begin{array}{c}\text { Site } 2 \\
(\%)\end{array}$ & $\begin{array}{c}\text { Site } 3 \\
(\%)\end{array}$ & $\begin{array}{c}\text { Site } 4 \\
(\%)\end{array}$ & $\begin{array}{c}\text { Total } \\
(\%)\end{array}$ \\
\hline Fell & 0.06 & 0.77 & 0.71 & 0.44 & 0.48 & 0.77 & 17.46 & 4.93 & 1.80 & 3.64 \\
\hline Skid & 0.03 & $<0.01$ & $<0.01$ & 0.03 & 0.02 & 0.98 & 0.31 & 0.17 & 0.28 & 0.30 \\
\hline Deck & $<0.01$ & 0.03 & 0.05 & 0.02 & 0.03 & 0.56 & 1.02 & 0.45 & 0.17 & 0.44 \\
\hline Load & $<0.01$ & 0.01 & $<0.01$ & $<0.01$ & $<0.01$ & 0.25 & 0.39 & 0.16 & 0.08 & 0.23 \\
\hline Total (\%) & 0.03 & 0.16 & 0.20 & 0.14 & & 0.64 & 5.69 & 2.48 & 1.07 & \\
\hline
\end{tabular}

\subsubsection{Volume and Value Loss by Site and Species}

Volume loss by site and species shows the largest average volume losses occurring to white ash, white oak, yellow-poplar, sugar maple, and black cherry 
respectively, with percentages ranging from 1.11-percent to 0.13-percent (Table 3.5).

Red oak and chestnut oak show the lowest average volume losses per log with values of 0.08-percent and 0.04-percent respectively.

Table 3.5 - Percentage of total volume lost (BF) per log and damaged log by site and species*.

\begin{tabular}{|c|c|c|c|c|c|c|c|c|c|c|}
\hline & \multicolumn{4}{|c|}{ Observed Logs } & \multicolumn{6}{|c|}{ Damaged Logs } \\
\hline Species & $\begin{array}{c}\text { Site 1 } \\
(\%)\end{array}$ & $\begin{array}{c}\text { Site } 2 \\
(\%)\end{array}$ & $\begin{array}{c}\text { Site 3 } \\
(\%)\end{array}$ & $\begin{array}{c}\text { Site } 4 \\
(\%)\end{array}$ & $\begin{array}{c}\text { Total } \\
(\%)\end{array}$ & $\begin{array}{c}\text { Site } 1 \\
(\%)\end{array}$ & $\begin{array}{c}\text { Site } 2 \\
(\%)\end{array}$ & $\begin{array}{c}\text { Site } 3 \\
(\%)\end{array}$ & $\begin{array}{c}\text { Site } 4 \\
(\%)\end{array}$ & $\begin{array}{c}\text { Total } \\
(\%)\end{array}$ \\
\hline $\mathrm{BC}$ & 0.00 & 0.12 & 0.20 & 0.02 & 0.13 & 0.00 & 7.53 & 3.18 & 0.21 & 3.25 \\
\hline $\mathrm{CO}$ & 0.02 & 0.02 & 0.12 & 0.02 & 0.04 & 0.53 & 15.31 & 1.18 & 0.09 & 0.68 \\
\hline RO & 0.02 & 0.02 & 0.22 & 0.06 & 0.08 & 0.77 & 0.34 & 2.23 & 0.67 & 1.27 \\
\hline $\mathrm{SM}$ & 0.03 & 0.04 & 0.00 & 0.24 & 0.14 & 0.81 & 5.56 & 0.00 & 1.53 & 1.50 \\
\hline WA & 0.10 & 1.46 & 1.01 & 0.03 & 1.11 & 7.40 & 26.59 & 6.84 & 7.41 & 15.70 \\
\hline WO & 0.05 & 1.22 & 0.06 & 0.06 & 0.29 & 0.63 & 12.07 & 0.28 & 0.49 & 1.96 \\
\hline YP & 0.03 & 0.10 & 0.25 & 0.10 & 0.15 & 0.47 & 8.37 & 3.60 & 1.19 & 2.50 \\
\hline Total (\%) & 0.03 & 0.16 & 0.20 & 0.14 & & 0.64 & 5.69 & 2.48 & 1.07 & \\
\hline
\end{tabular}

Value loss per log by site and species shows the largest average value losses occurring to white ash, white oak, and sugar maple (Table 3.6). These value losses ranged from 1.15-percent to 0.14-percent. Yellow-poplar and black cherry show the 
same average value loss, both with values of 0.12 -percent. Red oak and chestnut oak had average value losses of 0.08 -percent and 0.03 -percent per log respectively.

Table 3.6 - Percentage of total value lost (\$) per log and damaged log by site and species.

Observed Logs

Damaged Logs

\begin{tabular}{ccccccccccc}
\hline Species & $\begin{array}{c}\text { Site 1 } \\
(\%)\end{array}$ & $\begin{array}{c}\text { Site 2 } \\
(\%)\end{array}$ & $\begin{array}{c}\text { Site 3 } \\
(\boldsymbol{\%})\end{array}$ & $\begin{array}{c}\text { Site 4 } \\
(\boldsymbol{\%})\end{array}$ & $\begin{array}{c}\text { Total } \\
(\boldsymbol{\%})\end{array}$ & $\begin{array}{c}\text { Site 1 } \\
(\boldsymbol{\%})\end{array}$ & $\begin{array}{c}\text { Site 2 } \\
(\boldsymbol{\%})\end{array}$ & $\begin{array}{c}\text { Site 3 } \\
(\boldsymbol{\%})\end{array}$ & $\begin{array}{c}\text { Site 4 } \\
(\boldsymbol{\%})\end{array}$ & $\begin{array}{c}\text { Total } \\
(\boldsymbol{\%})\end{array}$ \\
\hline BC & 0 & 0.13 & 0.18 & 0.02 & $\mathbf{0 . 1 2}$ & 0 & 7.71 & 2.82 & 0.19 & $\mathbf{3 . 1 2}$ \\
CO & 0.02 & $<0.01$ & 0.08 & 0.01 & $\mathbf{0 . 0 3}$ & 0.52 & 0.51 & 0.94 & 0.07 & $\mathbf{0 . 6 1}$ \\
RO & 0.02 & 0.02 & 0.22 & 0.06 & $\mathbf{0 . 0 8}$ & 0.68 & 0.34 & 2.22 & 0.6 & $\mathbf{1 . 2 5}$ \\
SM & 0.04 & 0.02 & 0 & 0.23 & $\mathbf{0 . 1 4}$ & 0.79 & 5.56 & 0 & 1.4 & $\mathbf{1 . 3 6}$ \\
WA & 0.05 & 1.47 & 1.03 & 0.04 & $\mathbf{1 . 1 5}$ & 7.41 & 27.65 & 6.84 & 0.2 & $\mathbf{1 5 . 4 8}$ \\
WO & 0.04 & 1.12 & 0.06 & 0.07 & $\mathbf{0 . 2 8}$ & 0.49 & 11.06 & 0.42 & 0.329 & $\mathbf{1 . 8 8}$ \\
YP & 0.03 & 0.08 & 0.21 & 0.1 & $\mathbf{0 . 1 2}$ & 0.47 & 8.08 & 2.87 & 1.31 & $\mathbf{2 . 2 3}$ \\
\hline Total (\%) & $\mathbf{0 . 0 3}$ & $\mathbf{0 . 1 6}$ & $\mathbf{0 . 2 0}$ & $\mathbf{0 . 1 4}$ & & $\mathbf{0 . 6 4}$ & $\mathbf{5 . 6 9}$ & $\mathbf{2 . 4 8}$ & $\mathbf{1 . 0 7}$ & \\
\hline
\end{tabular}




\subsubsection{Volume and Value Loss by Site and Damage Type}

Damage volume loss by harvest site and damage type suggests the majority of woody tissue damage is caused by splits and slabs (Table 3.7). Gouges and scrapes caused a small amount of average volume loss per damaged log.

\begin{tabular}{|c|c|c|c|c|c|}
\hline \multicolumn{6}{|c|}{$\begin{array}{c}\text { Observed/Damaged } \\
\text { Logs }\end{array}$} \\
\hline Type* & $\begin{array}{c}\text { Site 1 } \\
(\%)\end{array}$ & $\begin{array}{c}\text { Site } 2 \\
(\%)\end{array}$ & $\begin{array}{c}\text { Site } 3 \\
(\%)\end{array}$ & $\begin{array}{c}\text { Site } 4 \\
(\%)\end{array}$ & $\begin{array}{r}\text { Total } \\
(\%)\end{array}$ \\
\hline ND & - & - & - & - & - \\
\hline GG & 0.59 & 0.69 & 0.21 & 0.20 & 0.31 \\
\hline SLB & 0.69 & - & 7.00 & 2.03 & 3.13 \\
\hline SPT & 0.70 & 11.30 & 5.25 & 2.73 & 5.77 \\
\hline SCP & - & - & 0.17 & 0.42 & 0.37 \\
\hline Total (\%) & $\begin{array}{l}0.64 \\
\end{array}$ & 5.69 & 2.48 & 1.07 & \\
\hline
\end{tabular}

Value loss per log by harvest site and damage type shows the majority of woody tissue value loss being caused by splits and slabs (Table 3.8). Value loss associated with splits was 4.92-percent, and value loss associated with slabs was 1.97-percent. 
Table 3.8 - Percentage of total value lost (\$) per log and damaged log by site and damage type.

\begin{tabular}{cccccc}
\multicolumn{7}{c}{ Observed/Damaged } \\
Logs \\
Type* & $\begin{array}{c}\text { Site 1 } \\
(\boldsymbol{\%})\end{array}$ & $\begin{array}{c}\text { Site } 2 \\
(\boldsymbol{\%})\end{array}$ & $\begin{array}{c}\text { Site 3 } \\
(\boldsymbol{\%})\end{array}$ & $\begin{array}{c}\text { Site 4 } \\
(\boldsymbol{\%})\end{array}$ & $\begin{array}{c}\text { Total } \\
(\boldsymbol{\%})\end{array}$ \\
\hline ND & - & - & - & - & - \\
GG & 0.63 & 0.88 & 0.17 & 0.19 & $\mathbf{0 . 3 3}$ \\
SLB & 0.73 & - & 4.66 & 1.41 & $\mathbf{1 . 9 7}$ \\
SPT & 0.51 & 8.99 & 4.55 & 3.09 & $\mathbf{4 . 9 2}$ \\
SCP & - & - & 0.14 & 0.3 & $\mathbf{0 . 2 6}$ \\
\hline Total $(\%)$ & $\mathbf{0 . 6 4}$ & $\mathbf{5 . 6 9}$ & $\mathbf{2 . 4 8}$ & $\mathbf{1 . 0 7}$ \\
\hline
\end{tabular}

\subsubsection{Volume and Value Loss by Site and Log Grade}

Volume loss per log by harvest site and log grade shows most of the woody tissue volume loss occurring to grade 2 saw logs which had a value of 0.26-percent (Table 3.9). Grade 1 and grade 3 saw logs show the least amount of average volume loss per $\log$ with values of 0.13 -percent and 0.12 -percent. 
Table 3.9 - Percentage of volume loss (BF) by site and grade.

\begin{tabular}{|c|c|c|c|c|c|c|c|c|c|c|}
\hline & \multicolumn{4}{|c|}{ Observed Logs } & \multicolumn{6}{|c|}{ Damaged Logs } \\
\hline Grade & $\begin{array}{c}\text { Site } 1 \\
(\%)\end{array}$ & $\begin{array}{c}\text { Site } 2 \\
(\$)\end{array}$ & $\begin{array}{c}\text { Site } 3 \\
(\$)\end{array}$ & $\begin{array}{c}\text { Site } 4 \\
(\$)\end{array}$ & $\begin{array}{c}\text { Total } \\
(\%)\end{array}$ & $\begin{array}{c}\text { Site } 1 \\
(\%)\end{array}$ & $\begin{array}{c}\text { Site } 2 \\
(\$)\end{array}$ & $\begin{array}{c}\text { Site } 3 \\
(\$)\end{array}$ & $\begin{array}{c}\text { Site } 4 \\
(\$)\end{array}$ & $\begin{array}{c}\text { Total } \\
(\%)\end{array}$ \\
\hline 1 & 0.02 & 0.19 & 0.16 & 0.11 & 0.13 & 0.52 & 6.28 & 1.82 & 0.88 & 1.83 \\
\hline 2 & 0.02 & 0.41 & 0.43 & 0.16 & 0.26 & 0.87 & 14.29 & 8.88 & 1.57 & 4.75 \\
\hline 3 & 0.05 & 0.02 & 0.63 & 0.06 & 0.12 & 1.2 & 3.13 & 8.4 & 0.71 & 2.28 \\
\hline Total (\%) & 0.03 & 0.16 & 0.20 & 0.14 & & 0.64 & 5.69 & 2.48 & 1.07 & \\
\hline
\end{tabular}

Value loss per log by harvest site and log grade shows most of the woody tissue value loss occurring to grade 2 saw logs (Table 3.10). Grade 2 saw logs show an average value loss per log of 0.21 -percent. Grade 1 and grade 2 saw logs show the least amount of average value loss, both showing a value of 0.12 -percent per log.

Table 3. 10 - Percentage of total value lost (\$) per log and damaged log by site and grade.

Observed Logs

Damaged Logs

\begin{tabular}{ccccccccccc}
\hline Grade & $\begin{array}{c}\text { Site 1 } \\
(\boldsymbol{\%})\end{array}$ & $\begin{array}{c}\text { Site 2 } \\
(\boldsymbol{\%})\end{array}$ & $\begin{array}{c}\text { Site 3 } \\
(\boldsymbol{\%})\end{array}$ & $\begin{array}{c}\text { Site 4 } \\
(\boldsymbol{\%})\end{array}$ & $\begin{array}{c}\text { Total } \\
(\boldsymbol{\%})\end{array}$ & $\begin{array}{c}\text { Site 1 } \\
(\boldsymbol{\%})\end{array}$ & $\begin{array}{c}\text { Site 2 } \\
(\boldsymbol{\%})\end{array}$ & $\begin{array}{c}\text { Site 3 } \\
(\boldsymbol{\%})\end{array}$ & $\begin{array}{c}\text { Site 4 } \\
(\boldsymbol{\%})\end{array}$ & $\begin{array}{c}\text { Total } \\
(\boldsymbol{\%})\end{array}$ \\
\hline 1 & 0.02 & 0.13 & 0.17 & 0.13 & $\mathbf{0 . 1 2}$ & 0.59 & 4.71 & 1.89 & 0.92 & $\mathbf{1 . 6 4}$ \\
2 & 0.01 & 0.25 & 0.34 & 0.19 & $\mathbf{0 . 2 1}$ & 0.93 & 12.61 & 7.58 & 1.77 & $\mathbf{4 . 0 2}$ \\
3 & 0.06 & 0.05 & 0.54 & 0.05 & $\mathbf{0 . 1 2}$ & 1.16 & 3.13 & 6.68 & 0.67 & $\mathbf{2 . 4 5}$ \\
\hline Total $(\%)$ & $\mathbf{0 . 0 3}$ & $\mathbf{0 . 1 6}$ & $\mathbf{0 . 2 0}$ & $\mathbf{0 . 1 4}$ & & $\mathbf{0 . 6 4}$ & $\mathbf{5 . 6 9}$ & $\mathbf{2 . 4 8}$ & $\mathbf{1 . 0 7}$ \\
\hline
\end{tabular}




\subsubsection{Veneer Value and Degrade}

A total of 175 hardwood logs were chosen for the veneer log comparisons. The total volume calculated for the veneer data set was 22,197 BF (Table 3.11). This volume had a total value of $\$ 43,695.08$. The degraded veneer logs had a value of $\$ 19,302.00$. The value loss associated with degrade was $\$ 24,393.08$. The average percentage of value loss per degraded veneer log was approximately 55-percent.

\section{Table 3.11 - Hardwood veneer value and degrade value.}

\begin{tabular}{|c|c|c|c|c|c|c|c|c|}
\hline Species & $\begin{array}{c}\text { No. of } \\
\text { Logs }\end{array}$ & Grade & $\begin{array}{c}\text { Volume } \\
\text { (BF) }\end{array}$ & $\begin{array}{c}\text { Veneer } \\
\text { Value } \\
(\$)\end{array}$ & $\begin{array}{c}\text { Grade } \\
\text { Value } \\
(\$)\end{array}$ & $\begin{array}{c}\text { Value } \\
\text { Loss } \\
(\$) \\
\end{array}$ & $\begin{array}{c}\text { Total } \\
\text { Value } \\
\text { Loss } \\
(\%) \\
\end{array}$ & $\begin{array}{c}\text { Avg. } \\
\text { Value } \\
\text { Loss } \\
(\%) \\
\end{array}$ \\
\hline \multirow[t]{3}{*}{$\mathrm{BC}$} & 33 & 1 & $1,586.00$ & $5,852.34$ & $2,188.68$ & $3,663.66$ & 62.60 & \\
\hline & & 2 & $1,062.50$ & $3,920.62$ & $1,051.87$ & $2,868.75$ & 73.17 & 69.05 \\
\hline & & 3 & 276.00 & $1,018.44$ & 99.36 & 919.08 & 90.24 & \\
\hline \multirow[t]{3}{*}{ RO } & 84 & 1 & $10,756.50$ & $16,672.57$ & $9,143.02$ & $7,529.55$ & 45.16 & \\
\hline & & 2 & $1,769.00$ & $2,741.95$ & $1,220.61$ & $1,521.34$ & 55.48 & 47.74 \\
\hline & & 3 & 389.00 & 602.95 & 97.25 & 505.70 & 83.87 & \\
\hline \multirow[t]{3}{*}{ SM } & 38 & 1 & $2,370.00$ & $5,214.00$ & $3,507.60$ & $1,706.40$ & 32.73 & \\
\hline & & 2 & $1,019.00$ & $2,241.80$ & 713.30 & $1,528.50$ & 68.18 & 47.60 \\
\hline & & 3 & 381.50 & 839.30 & 125.89 & 713.41 & 85.00 & \\
\hline \multirow[t]{3}{*}{ WA } & 7 & 1 & 729.00 & $1,239.30$ & 335.34 & 903.96 & 72.94 & \\
\hline & & 2 & 100.00 & 170.00 & 27.00 & 143.00 & 84.12 & 74.65 \\
\hline & & 3 & 18.00 & 30.60 & 2.70 & 27.90 & 91.18 & \\
\hline \multirow[t]{3}{*}{ WO } & 13 & 1 & $1,438.00$ & $2,602.78$ & 704.62 & $1,898.16$ & 72.93 & \\
\hline & & 2 & 175.00 & 316.75 & 63.00 & 253.75 & 80.11 & 75.00 \\
\hline & & 3 & 128.00 & 231.68 & 21.76 & 209.92 & 90.61 & \\
\hline Total & 175 & & $22,197.50$ & $43,695.08$ & $19,302.00$ & $24,393.08$ & 55.83 & \\
\hline
\end{tabular}




\subsubsection{Comparisons of Damage}

The differences in damage value and damage volume were examined among harvesting system, terrain slope, harvest function, species, damage type, and log grade. Using Duncan's New Multiple Range Test at a five-percent level, these variables were looked at to determine any effect they may have on saw log damage volume and value.

\subsubsection{Harvesting System}

There were significant differences in damage volume among the harvesting systems $(\mathrm{F}=6.47 ; \mathrm{df}=3 ; \mathrm{P}=0.0002)$. There is no significant difference in damage volume between manual site 1 and manual site 2 , or any significant difference in damage volume between mechanized site 1 and mechanized site 2 (Table 3.12). However, the damage volume is different between manual sites and mechanized sites. 


\section{Table 3. 12 - Damage volume by harvesting system.}

\begin{tabular}{ccc}
\hline System & $\begin{array}{c}\text { No. of } \\
\text { Observations } \\
(\mathbf{n})\end{array}$ & $\begin{array}{c}\text { Mean* }^{*} \\
(\mathbf{B F} / \mathbf{l o g})\end{array}$ \\
\hline Manual 2 & 1000 & $0.296 \mathrm{a}$ \\
Manual 1 & 1000 & $0.286 \mathrm{a}$ \\
Mechanized 2 & 1000 & $0.133 \mathrm{~b}$ \\
Mechanized 1 & 1000 & $0.030 \mathrm{~b}$ \\
\hline Means with a different letter in a column are significantly different at the 5\% level.
\end{tabular}

Significant differences in damage value also existed among harvesting systems $(\mathrm{F}=6.09 ; \mathrm{df}=3 ; \mathrm{P}=0.004)$. There is no significant difference in saw log damage value between manual site 2, manual site 1 , and mechanized site 2 (Table 3.13). There is a significant difference between these three sites and mechanized site 1.

Table 3.13 - Damage value by harvesting system.

\begin{tabular}{ccc}
\hline System & $\begin{array}{c}\text { No. of } \\
\text { Observations } \\
(\mathbf{n})\end{array}$ & $\begin{array}{c}\text { Mean } \\
\mathbf{( \$ / / o g})\end{array}$ \\
\hline Manual 2 & 1000 & $0.15 \mathrm{a}$ \\
Manual 1 & 1000 & $0.14 \mathrm{a}$ \\
Mechanized 2 & 1000 & $0.11 \mathrm{a}$ \\
Mechanized 1 & 1000 & $0.02 \mathrm{~b}$ \\
\hline
\end{tabular}




\subsubsection{Terrain Slope}

Terrain slope damage volume $(\mathrm{F}=6.47 ; \mathrm{df}=3 ; \mathrm{P}=0.0002)$ shows that there is no significant difference between the $20-25 \%$ slope class and the $5-15 \%$ slope class, or any significant difference in damage volume between $15-25 \%$ slope class and the 5-10\% slope class (Table 3.14). Damage value $(\mathrm{F}=6.09 ; \mathrm{df}=3 ; \mathrm{P}=0.0004)$ is not significantly different between the $20-25 \%$ slope class, the $5-15 \%$ slope class, and the 15-25\% slope class (Table 3.15). A significant difference in damage value is shown between these three slope classes and the 5-10\% slope class.

Table 3. 14 - Damage volume by terrain slope.

\begin{tabular}{ccc}
\hline Slope & $\begin{array}{c}\text { No. of } \\
\text { Observations } \\
(\mathbf{n})\end{array}$ & $\begin{array}{c}\text { Mean } \\
(\text { BF/log) }\end{array}$ \\
\hline $20-25 \%$ & 1000 & $0.296 \mathrm{a}$ \\
$5-15 \%$ & 1000 & $0.286 \mathrm{a}$ \\
$15-25 \%$ & 1000 & $0.133 \mathrm{~b}$ \\
$5-10 \%$ & 1000 & $0.03 \mathrm{~b}$ \\
\hline
\end{tabular}


Table 3.15 - Damage value by terrain slope.

\begin{tabular}{ccc}
\hline Slope & $\begin{array}{c}\text { No. of } \\
\text { Observations } \\
(\mathbf{n})\end{array}$ & $\begin{array}{c}\text { Mean } \\
(\$ / / o g)\end{array}$ \\
\hline $20-25 \%$ & 1000 & $0.15 \mathrm{a}$ \\
$5-15 \%$ & 1000 & $0.14 \mathrm{a}$ \\
$15-25 \%$ & 1000 & $0.11 \mathrm{a}$ \\
$5-10 \%$ & 1000 & $0.02 \mathrm{~b}$ \\
\hline
\end{tabular}

\subsubsection{Harvesting Function}

Damage volume differed significantly among harvesting functions $(\mathrm{F}=43.10 ; \mathrm{df}=$ 3; $\mathrm{P}=<0.0001$ ) (Table 3.16). Saw log damage value also showed a significant difference among functions $(\mathrm{F}=52.95 ; \mathrm{df}=3 ; \mathrm{P}=<0.0001)$ (Table 3.17).

\begin{tabular}{ccc}
\hline Table 3.16 - Damage volume by harvesting functions. \\
\hline $\begin{array}{c}\text { No. of } \\
\text { Function }\end{array}$ & $\begin{array}{c}\text { Mean } \\
(\mathbf{n})\end{array}$ & $\begin{array}{c}\text { MF/log) } \\
(\mathbf{B F}\end{array}$ \\
\hline FELL & 1000 & $0.682 \mathrm{a}$ \\
DECK & 1000 & $0.035 \mathrm{~b}$ \\
SKID & 1000 & $0.018 \mathrm{~b}$ \\
LOAD & 1000 & $0.01 \mathrm{~b}$ \\
\hline
\end{tabular}




\section{Table 3.17 - Damage value by harvesting functions.}

\begin{tabular}{ccc}
\hline Function & $\begin{array}{c}\text { No. of } \\
\text { Observations } \\
(\mathbf{n})\end{array}$ & $\begin{array}{c}\text { Mean } \\
\mathbf{( \$ / / o g})\end{array}$ \\
\hline FELL & 1000 & $0.38 \mathrm{a}$ \\
DECK & 1000 & $0.02 \mathrm{~b}$ \\
SKID & 1000 & $0.01 \mathrm{~b}$ \\
LOAD & 1000 & $0.01 \mathrm{~b}$ \\
\hline
\end{tabular}

\subsubsection{Species}

There were significant differences in damage volume among species $(\mathrm{F}=11.62$; $\mathrm{df}=6 ; \mathrm{P}=<0.0001)$. Damage volume for white ash is significantly different from all other species (Table 3.18). Damage volume for white oak significantly differed from white ash and chestnut oak, while damage volume for yellow-poplar, sugar maple, black cherry, red oak, and chestnut oak are not significantly different from one another. 


\section{Table 3. 18 - Damage volume by species.}

\begin{tabular}{ccc}
\hline Species & $\begin{array}{c}\text { No. of } \\
\text { Observations } \\
(\mathbf{n})\end{array}$ & $\begin{array}{c}\text { Mean } \\
(\mathbf{B F} / \mathbf{l o g})\end{array}$ \\
\hline WA & 144 & $1.2292 \mathrm{a}$ \\
WO & 162 & $0.3684 \mathrm{~b}$ \\
YP & 1421 & $0.1835 \mathrm{bc}$ \\
SM & 523 & $0.1458 \mathrm{bc}$ \\
BC & 455 & $0.1207 \mathrm{bc}$ \\
RO & 948 & $0.1104 \mathrm{bc}$ \\
CO & 347 & $0.0312 \mathrm{c}$ \\
\hline
\end{tabular}

There were also significant differences in damage value among species $(\mathrm{F}=$ 9.26; $\mathrm{df}=6 ; \mathrm{P}=<0.0001)$. Damage value for white ash was significantly different for all other species (Table 3.19). Damage value for sugar maple and white oak differed significantly from white ash and chestnut oak. However, there was no significance of damage value for black cherry, red oak, yellow-poplar, and chestnut oak. 
Table 3. 19 - Damage value by species.

\begin{tabular}{ccc}
\hline Species & $\begin{array}{c}\text { No. of } \\
\text { Observations } \\
(\mathbf{n})\end{array}$ & $\begin{array}{c}\text { Mean } \\
\mathbf{\$} / \mathbf{l o g})\end{array}$ \\
\hline WA & 144 & $0.51 \mathrm{a}$ \\
SM & 523 & $0.16 \mathrm{~b}$ \\
WO & 162 & $0.16 \mathrm{~b}$ \\
BC & 455 & $0.14 \mathrm{bc}$ \\
RO & 948 & $0.09 \mathrm{bc}$ \\
YP & 1421 & $0.06 \mathrm{bc}$ \\
CO & 347 & $0.01 \mathrm{c}$ \\
\hline
\end{tabular}

\subsubsection{Damage Type}

There were significant differences in damage volume among damage types $(\mathrm{F}=$ 457.39; $\mathrm{df}=4 ; \mathrm{P}=<0.0001)$. Damage volume by splits is significantly higher than the other damage types (Table 3.20). Damage volume by slabs is significantly different from gouge damage and scrape damage. There is no significant difference in damage volume between gouge damage and scrape damage. 


\section{Table 3.20 - Damage volume by damage type.}

\begin{tabular}{ccc}
\hline & $\begin{array}{c}\text { No. of } \\
\text { Observations } \\
\text { Damage Type }\end{array}$ & $\begin{array}{c}\text { Mean } \\
\text { (BF/log) }\end{array}$ \\
\hline SPT & 67 & $7.83 \mathrm{a}$ \\
SLB & 39 & $4.22 \mathrm{~b}$ \\
GG & 95 & $0.45 \mathrm{c}$ \\
SCP & 30 & $0.40 \mathrm{c}$ \\
ND & 3769 & $0.00 \mathrm{c}$ \\
\hline
\end{tabular}

Significant differences in damage value existed among damage types ( $\mathrm{F}=578.28$; $\mathrm{df}=4 ; \mathrm{P}=<0.0001)$. There is a significant difference in damage value between split damage and the other damage types (Table 3.21). Damage value for slabs is significantly different from gouge damage and scrape damage. Damage value does not differ significantly between gouge damage and scrape damage. 


\section{Table 3.21 - Damage value by damage type.}

\begin{tabular}{ccc}
\hline $\begin{array}{c}\text { Damage } \\
\text { Type }\end{array}$ & $\begin{array}{c}\text { No. of } \\
\text { Observations } \\
(\mathbf{n})\end{array}$ & $\begin{array}{c}\text { Mean } \\
\mathbf{( \$ / / o g})\end{array}$ \\
\hline SPT & 67 & $4.42 \mathrm{a}$ \\
SLB & 39 & $2.12 \mathrm{~b}$ \\
GG & 95 & $0.31 \mathrm{c}$ \\
SCP & 30 & $0.16 \mathrm{~cd}$ \\
ND & 3769 & $0.00 \mathrm{~d}$ \\
\hline
\end{tabular}

\subsubsection{Log Grade}

There were significant differences in damage volume among log grades $(\mathrm{F}=1.57$; $\mathrm{df}=2 ; \mathrm{P}=0.2085)$. Damage volume shows no significant difference in between grade 1 and grade 2 hardwood saw logs (Table 3.22). Grade 1 and grade 2 saw logs show a significant difference in damage volume from grade 3 saw logs. 
Table 3. 22 - Damage volume by saw log grade.

\begin{tabular}{ccc}
\hline Grade & $\begin{array}{c}\text { No. of Observations } \\
(\mathbf{n})\end{array}$ & $\begin{array}{c}\text { Mean } \\
(\mathbf{B F} / \mathbf{l o g})\end{array}$ \\
\hline 1 & 1965 & $0.22 \mathrm{a}$ \\
2 & 1286 & $0.208 \mathrm{a}$ \\
3 & 749 & $0.06 \mathrm{~b}$ \\
\hline
\end{tabular}

Correspondingly, there was a significant difference in damage value among log grades $(F=4.60 ; \mathrm{df}=2 ; \mathrm{P}=0.0091)$. Damage value shows no significant difference between grade 1 and grade 2 hardwood saw logs (Table 3.23). There is a significant difference in damage value between these two log grades and the remaining grade 3 saw logs.

Table 3. 23 - Damage value by saw log grade.

\begin{tabular}{ccc}
\hline Grade & $\begin{array}{c}\text { No. of Observations } \\
(\mathbf{n})\end{array}$ & $\begin{array}{c}\text { Mean } \\
(\$ / \mathbf{l o g})\end{array}$ \\
\hline 1 & 1965 & $0.15 \mathrm{a}$ \\
2 & 1286 & $0.09 \mathrm{a}$ \\
3 & 749 & $0.01 \mathrm{~b}$ \\
\hline
\end{tabular}




\subsubsection{Questionnaire}

The industry response was summarized based on a questionnaire, which dealt with the hauling function of the timber harvesting process, causes of damage to harvested saw logs, volume and value lost during the harvesting process, and guidelines or training that should be implemented to create monetary gains. There were 55 questionnaires sent to various hardwood lumber producers and loggers. A total of 24 questionnaires were returned, with a 43.7-percent return rate.

Of the 24 questionnaires received, 21 stated that hardwood saw logs do not lose value or volume due to damage caused by the hauling process. In response to what causes the majority of the damage to hardwood saw $\operatorname{logs}, 21$ answered felling, 13 answered bucking, 10 answered extraction, 4 answered loading, 2 answered unloading, and 1 answered bucking.

In response to what were the most common damage types, 15 answered breaks or splits, 13 answered felling shatter, 8 answered saw chain cuts, 7 answered grapple gouges, 7 answered barberchairs, 5 answered slabs, 2 answered bucksaw breakage, 2 answered loader forks, and 1 answered bucking mismeasurement. Regarding the damage type which caused the most volume or value loss, 16 answered felling shatter, 13 answered breaks or splits, 8 answered barberchairs, 6 answered slabs, 4 answered improper bucking, 2 answered saw chain cuts, and 2 answered grapple gouges.

In response to what percentage of value or volume is lost per log due to damage caused by the harvesting process, the average value loss was $15 \%$, and the average volume loss was $11 \%$. When asked if there were potential for monetary gains 
to be made by implementing new guidelines or training to minimize damage to harvested hardwood saw logs, 20 out of 24 answered yes. Some of the guidelines mentioned were the following:

(1) Bringing tree length logs to the mill.

(2) Emphasis on directional felling.

(3) More focus on cost and value rather than volume alone.

(4) More conscientious skidder operation.

(5) Promoting a more prideful attitude of the logging profession.

(6) No tree length log skidding.

(7) Use of the "Game of Logging.*"

(8) SFI training

(9) Chainsaw training.

Some comments offered by the respondents on how to minimize or eliminate damage to harvested hardwood saw logs included:

(1) Better attention paid to first 2 feet of the butt log during felling.

(2) Pay loggers for value rather than volume.

(3) Education for loggers on how to cut grade.

(4) Coat log ends.

(5) Pile logs quickly. 
(6) Water log piles.

(7) Use white woods logs quickly after harvest.

(8) Plan switchbacks better.

(9) Grab logs with grapple rather than pinching the log.

(10) Log bucking training.

(11) Greater reprimands for careless logging practices (such as termination of employment or reduction of pay).

(12) Professional tree toppers for standing veneer.

(13) Use of a feller-buncher.

*Game of Logging refers to instruction in directional felling, safety, and chainsaw maintenance for timber cutters. 


\section{H A P T E R 4 - S U M M A R Y A N D D I S C US S I O N}

\subsection{Saw Log Volume and Value Loss}

Saw log value loss is the main focus of this research. The goal was to determine if damage to hardwood saw logs caused by the harvesting process was a problem. Total value for the entire data set equaled $\$ 305,107.17$. Post-damage value for the entire data set equaled $\$ 304,694.48$. The difference between the total value and the post-damage value is $\$ 412.69$. Spread across a sample size of 4000 hardwood saw $\operatorname{logs}$, the value loss equates to approximately $\$ 0.10$ of value lost per log.

Saw log volume loss is also an important area of focus. Total volume for the data set was 476,460.5 BF. Post-damage volume for the data set was 475,716.4 BF. The difference between the total volume and the post-damage volume was $744.08 \mathrm{BF}$. Over the entire data set of 4000 saw logs, the volume loss equals 0.19 BF per log.

A total of 231 hardwood saw logs were damaged severely enough to cause woody tissue loss, equating to approximately 6-percent of the logs sampled. Average value loss for the damaged saw logs equals $\$ 1.79$ per log. Correspondingly, the average volume lost per damaged log equals 3.22 BF. Using the Doyle log rule scale, an 18inch diameter, 16 foot long, grade 1 red oak saw log equals 196 BF. Supposing the timber market price of $\$ 850$ per $\mathrm{MBF}$, this log has a value of $\$ 166$. A value loss of $\$ 1.79$ is equal to 1 -percent of that log's value. So, in essence, when a saw $\log$ is 
damaged, the average value lost per log is approximately 1-percent of the total value of that log. The actual value loss per log varies based on species and log grade.

\subsubsection{Harvesting System}

There was more damage caused by the manual harvesting systems than the mechanized harvesting systems. Damage volume caused by manual systems totaled 581.86 BF, over three times more damage volume than the mechanized system, which had a total damage volume of $165.77 \mathrm{BF}$. Value loss caused by the manual systems totaled \$291.76, twice as much value loss than the mechanized system, which had a total value loss of $\$ 123.84$.

There was a significant difference in damage volume between the manual harvesting systems and the mechanized harvesting systems. Average damage volume found for the manual systems overall was $0.29 \mathrm{BF}$ per log or 6.06 BF per damaged log. Average damage volume for the mechanized harvesting systems overall was 0.08 BF per log, or 1.22 BF pr damaged log. On average, the manual systems caused saw logs approximately $0.21 \mathrm{BF}$ more volume damage per log, or $4.84 \mathrm{BF}$ more volume damage per damaged log, than the mechanized systems. It could be said that manual systems cause more damage volume to hardwood saw logs on average than mechanized systems. 
Value loss of damaged saw logs differed between harvesting systems. The manual systems presented the highest average value loss with an overall damage value of $\$ 0.15$ per log, or $\$ 3.04$ per damaged log. Also, one of the mechanized systems had the lowest average value loss with a value of $\$ 0.02$ per log, or $\$ 0.92$ per damaged log. It can be concluded that, on average, manual harvesting systems cause more value damage than mechanized harvesting systems.

\subsubsection{Terrain Slope}

A significant difference was found between the two lower slope classes (5-10\% and 5-15\%) and the two higher slope classes (15-25\% and 20-25\%). Total volume loss for the higher slope classes equaled $431.11 \mathrm{BF}$, over $100 \mathrm{BF}$ higher than the damage volume loss found for the lower slope classes, which had a total of $316.52 \mathrm{BF}$. Total value loss was also greater for the higher slope classes, which had a total value of $\$ 256.31$. The lower slope classes had a total value loss of $\$ 159.29$, almost $\$ 100.00$ less than the higher slope classes.

There was a significant difference in damage volume between the lower slope classes and the higher slope classes. The greatest average damage volume was found to be $0.296 \mathrm{BF}$ per $\log$, or $4.05 \mathrm{BF}$ per damaged log and was caused by the $20-25 \%$ slope class. The $5-15 \%$ slope class showed $0.286 \mathrm{BF}$ of damage volume per log, or 12.43 BF of damage volume per damaged log. The $15-25 \%$ slope class showed an average damage volume of $0.133 \mathrm{BF}$ per log, or $1.39 \mathrm{BF}$ per damaged log. The $5-10 \%$ 
slope class showed the least amount of average damage volume with $0.030 \mathrm{BF}$ per log, or $0.80 \mathrm{BF}$ per damaged log. More damage volume was found on the sites with higher slope classes.

There were no significant differences in damage value loss among the three highest slope classes $(20-25 \%, 5-15 \%$, and $15-25 \%)$ with the average values of $\$ 0.15$, $\$ 0.14$, and $\$ 0.11$ per $\log$, or $\$ 2.07, \$ 6.11$, and $\$ 1.08$ per damaged log, respectively. However, the lowest slope class of 5-10\% was significantly different from the higher slope classes, and showed an average damage value loss of $\$ 0.02$ per log, or $\$ 0.49$ per damaged log. The damage value loss in the lowest slope class caused, on average, less damage than the other slope classes.

\subsubsection{Harvesting Function}

There was a significant difference between the felling function and the other three functions (skidding decking, and loading). The felling function produced $683.42 \mathrm{BF}$ in damage volume, which was almost 19 times greater than the $36.25 \mathrm{BF}$ in total damage volume caused by the decking function. Skidding caused half a much damage as decking with $18.32 \mathrm{BF}$, and the loading function caused about half as much damage as the skidding function with a total of $9.64 \mathrm{BF}$.

The same effect was noted in the total value loss results. Felling caused a total of \$375.08 in damage value, approximately 17 times greater than the decking function, 
which caused a total value loss of $\$ 22.82$. The skidding and loading functions caused $\$ 12.93$ and $\$ 4.77$ in damage value loss respectively.

There was a significant difference in damage volume among the harvesting functions. Average damage volume for felling was much higher than the remaining three functions, and was significantly different. The average damage volume caused by the felling function was $0.682 \mathrm{BF}$ per $\log$, or $6.30 \mathrm{BF}$ per damaged log. The decking function caused, on average, $0.035 \mathrm{BF}$ of damage volume per log, or $0.70 \mathrm{BF}$ of damage volume per damaged log. The skidding function caused an average damage volume of $0.018 \mathrm{BF}$ per log, or $0.42 \mathrm{BF}$ per damaged log. The least amount of volume damage was caused by the loading function, which had a value of $0.010 \mathrm{BF}$ per log, or 0.37 per damaged log. Volume loss was not significantly different among the decking, skidding, and loading functions. The felling function caused, on average, more damage than the decking, skidding, and loading functions.

Value loss followed the same path as the volume loss for the harvesting functions. The felling function caused more value loss than the other three functions with an average value loss of $\$ 0.38$ per log, or $\$ 3.44$ per damaged log, and was significantly different from the decking, skidding, and loading functions. The decking function showed an average value loss of $\$ 0.02$ per log, or $\$ 0.44$ per damaged log, the skidding and showed an average value lo ss of $\$ 0.01$ per log, or $\$ 0.30$ per damaged log, and the loading function showed an average value loss of $\$ 0.01$ per log, or $\$ 0.18$ per damaged log. There was no significant difference in value loss among the decking, skidding, and loading functions. The felling function caused more value loss than the decking, skidding, and loading functions. 


\subsubsection{Species}

Differences among species ranged from 260.44 BF to $1206 \mathrm{BF}$ for total damage volume, and from $\$ 84.05$ to $\$ 2.23$ for total value loss. The greatest total volume was suffered by yellow-poplar, which had a volume loss of $260.44 \mathrm{BF}$. White ash showed a volume loss of $177.00 \mathrm{BF}$, red oak lost a total of $104.51 \mathrm{BF}$, and sugar maple lost a total of 75.27 BF. White oak and black cherry showed similar total volume losses with $59.68 \mathrm{BF}$ and $54.95 \mathrm{BF}$, respectively. The least amount of volume loss was caused to chestnut oak, which had a total loss of only $12.06 \mathrm{BF}$.

The value loss suffered by the different species followed a slightly different pattern than the total volume loss. Red oak suffered the greatest total value loss with $\$ 84.05$. Sugar maple and yellow-poplar followed right behind with value losses of $\$ 83.51$ and $\$ 81.68$, respectively. White ash showed a total value loss of $\$ 73.37$, and black cherry had $\$ 60.00$ worth of damage caused to it. White oak suffered a total value loss of $\$ 25.19$, and chestnut oak showed a minimal total value loss of $\$ 2.23$.

Damage volume loss differed significantly among the different hardwood saw log species. Average damage volume for white ash was $1.230 \mathrm{BF}$ per log, or 22.13 BF per damaged log, while white oak showed an average volume loss of $0.368 \mathrm{BF}$ per log, or 3.32 BF per damaged log. Average volume losses of $0.184 \mathrm{BF}, 0.146 \mathrm{BF}, 0.121 \mathrm{BF}$, and 0.110 BF per log, or 3.02 BF, 1.88 BF, 3.66 BF, and 2.01 BF per damaged log were present for yellow-poplar, sugar maple, black cherry, and red oak respectively. 
Harvesting chestnut oak presented the least amount of average volume loss with a value of $0.031 \mathrm{BF}$ per $\log$, or $1.01 \mathrm{BF}$ per damaged log.

Damage value loss was significantly different among species. The greatest value loss of $\$ 0.51$ per $\log$, or $\$ 9.17$ per damaged log, was presented by white ash, which was significantly different from all the other species. Sugar maple and white oak showed the same value loss, both with values of $\$ 0.16$ per log, or $\$ 2.09$ and $\$ 1.40$ per damaged log respectively. Black cherry, red oak, and yellow-poplar showed average value losses of $\$ 0.14, \$ 0.09$, and $\$ 0.06$ per $\log$, or $\$ 4.00, \$ 1.62$, and $\$ 0.95$ per damaged log respectively. The least amount of value loss occurred when harvesting chestnut oak, with an average value loss of only $\$ 0.01$ per log, or $\$ 0.19$ per damaged $\log$.

\subsubsection{Damage Type}

Damage volumes significantly differed among the damage types. Damage volume loss caused by splits showed a value of $7.84 \mathrm{BF}$ per damaged log, and was significantly different from the other damage types. Slabbing caused an average volume loss of $4.22 \mathrm{BF}$ per damaged log and were significantly different from damage volumes caused by grapple gouge damage and scrape damage. Average damage volumes for grapple gouge damage and scrape damage were $0.45 \mathrm{BF}$ and $0.40 \mathrm{BF}$ per damaged log respectively. There were no significant differences among gouge damage and scrape damage. 
Correspondingly, value loss was significantly different among the damage types. Split damage accounted for an average value loss of $\$ 4.42$ per damaged log, and was significantly different from all other damage types. Slab damage had an average value loss of \$2.12 per damaged log, and was significantly different from grapple gouge damage and scrape damage, which had average value losses of $\$ 0.30$ and $\$ 0.16$ per damaged $\log$ respectively.

\subsubsection{Log Grade}

Differences in saw log damage volume existed among log grades. However, there was no significant difference in damage volume between grade 1 and grade 2 saw logs. Grade 1 showed an average damage volume of $0.220 \mathrm{BF}$ per log, or $3.31 \mathrm{BF}$ per damaged log, while grade 2 showed and average damage volume of 0.208 BF per log, or $4.10 \mathrm{BF}$ per damaged log. Average damage volume for grade 3 was $0.060 \mathrm{BF}$ per $\log$, or $1.16 \mathrm{BF}$ per damaged $\log$, and was significantly different from grade 1 and grade 2 saw logs.

Value loss among log grades mirrored the volume loss. There was no significant difference in damage value between grade 1 and grade 2 saw logs. Grade 1 showed an average value loss of $\$ 0.15$ per log, or $\$ 2.22$ per damaged log, and grade 2 showed and average value loss of $\$ 0.09$ per log, or $\$ 1.79$ per damaged log. Average value loss for grade 3 was $\$ 0.01$ per log, or $\$ 0.24$ per damaged log, and was less than grade 1 and grade 2 saw logs. 


\subsection{Veneer Log Value Loss}

Hardwood veneer total value in this study equaled $\$ 43,695.08$. After degrade from veneer to saw $\log$ grade, the total value equaled $\$ 19,302.00$. The difference between the total veneer value and the degrade value was $\$ 24,393.08$. The veneer data set included 175 randomly selected logs from the saw log data set. The average value loss per log due to degrade was $\$ 139.38$.

The value lost from hardwood veneer grade to saw log grade was much higher than the value loss caused by damage to hardwood saw logs. Again, actual value losses depend heavily on the species and grade of logs.

\subsection{Industry Response}

Some interesting results were produced based on the questionnaire. It seems that industry does not believe the hauling function causes hardwood saw logs to lose any value or volume. This limits the area of study to felling, skidding, bucking, decking, and loading. The replies from the questionnaire show the most concern to the areas of felling, bucking, and extraction, although responses did show that bucking losses were less than felling. This is consistent with the study because felling was found to cause the most damage, followed by decking and extraction. 
As for the damage type, the questionnaire results showed that splits were thought to be the most common form. The field data results show that this is not the case. The most common form of damage found were gouges caused by loader grapples. The questionnaire results also showed that felling shatter and splits were thought to be the damage types that caused the most volume or value loss. This was found to be true, with field results showing that splits caused by far the most value and volume loss.

The questionnaire results also indicated that respondents believe that average value loss and average volume loss suffered by hardwood saw logs were $15 \%$ and $11 \%$ respectively. Field results show that these figures are much lower. Average value loss in damaged saw logs was about $1 \%$ of the total saw log value. Average volume loss to damaged saw logs was about $2 \%$ of the total saw log volume.

Overall, the questionnaire indicated that loggers and saw mill owners believe that there was room for monetary gains to be made by implementing new guidelines or training to minimize damage to harvested hardwood saw logs. Many responses were geared towards the felling and bucking areas of the harvesting process, and suggestions were made towards making better use of timber cutter training and felling procedures, as well as focusing more on value rather than volume alone. 


\subsection{Discussion}

This study has shown that the majority of value loss caused by damage to hardwood saw logs is concentrated in one area. The damage caused by manual felling operations overshadows all other parts of the timber harvesting process. Even though this damage, by far, exceeds any other damage looked at in this study, the value loss associated with the manual felling process is still very minimal.

An interesting discovery was the difference in volume loss in selected species. White ash showed a large difference in volume and value loss compared to the other six species observed. One reason for this could be the mechanical properties of the species. It has been suggested in past studies that more brittle species have a greater susceptibility to damage than other species having more robust characteristics. Another reason for differences among species could be the time of harvest. Although, in this study all observations were made during leaf on conditions in the fall and spring, a different outcome may have been observed if this study had been conducted in the winter during leaf off conditions.

Another species-specific point to consider is the hardwood market. As demand for certain species rises and falls, more or less of that species may be harvested. Also, a high demand may generate greater care in harvesting certain species, whereas a low demand may be have the opposite effect.

The amount of damage caused to hardwood logs saw logs in this study may not seem important. This is especially true when looking at the difference between 
mechanized and manual harvesting systems. Is the amount of damage being caused to hardwood saw logs enough to justify and upgrade from chainsaw felling to a mechanized method? With the initial investment costs for making the switch to mechanized felling being several hundred thousand dollars, an average value loss of \$0.10 per log doesn’t seem very high.

The same scenario looks very different when dealing with veneer log degrade. An average value loss for veneer is upwards of $\$ 140.00$ per $\log$, which is over one thousand times greater than the average saw log value loss. Veneer grades have high standards, and sometimes just knocking the bark off a log warrants a degrade to a saw $\log$ grade.

Overall, this study supports many assumptions that have been made in the past. The most value loss was caused by a manual harvesting system, the most value loss was caused to saw logs harvested off sites with steeper slopes, the greatest value loss was caused by the felling function of the harvesting process, the major important hardwood species in this region consisting of red oak, yellow-poplar, black cherry, sugar maple, and white ash all showed very similar overall value losses, and veneer logs lose hundreds of dollars per log in value once they are degraded from veneer logs to grade logs. Damage to harvested saw logs is occurring on harvesting operations, but to a lesser degree than is perceived by the wood products industry.

There is room for improvement, as stated before, in manual felling operations. Industry suggestions found in the questionnaire call for more attention to be paid to the felling process. This could be accomplished by formal chainsaw felling 
instruction, and maybe by paying more attention to value and grade, rather than volume alone.

It is also possible that damage to harvested saw $\operatorname{logs}$ is likely to occur in different geographic areas, as this study was limited to north central West Virginia. Based on answers to the questionnaire, it seems that industry professionals believe that more damage, and consequently, more value loss is going on in the woods than is suggested in this study. Also, it is definitely possible that damage to harvested saw logs will vary from site to site, and maybe even within a single site.

There are other factors to consider that have not been dealt with in this study. An important area that needs attention is a harvest site's forest road network. It would be beneficial to determine how damage relates to skid trail density, road capacity, multiple landings and their locations, and length of skid. Along with these factors, terrain slope could be analyzed more closely, especially its correlation with the occurrence of switchbacks that may damage logs.

Further research is needed to determine the effects that other harvesting systems may have on saw log damage and value loss, as well as a more on depth analysis of the veneer log degrade. The information gained from the field study and the questionnaire used in this study may be important in creating new guidelines or training to help minimize hardwood log damage occurring during the timber harvesting process. Implementing new and better guidelines or training requirements could create monetary gains for loggers while better utilizing the forest's resources by not damaging valuable hardwood logs. 


\section{REFERENCES}

Avery T.E. and H.E. Burkhart. 1994. Forest Measurements. McGraw Hill, Inc., New York, NY.

Carpenter, R.D., D.L. Sonderman, E.D. Rast, and M.J. Jones. 1989. Defects in hardwood timber. U.S.D.A. Forest Service. Agricultural Handbook No. 678. Northeastern Forest Experiment Station. Delaware, $\mathrm{OH}$.

Cline, M.L., B.F. Hoffman, and M.W. Bragg. 1991. Stand damage following whole tree partial cutting in Northern forests. Northern Journal of Applied Forestry 8(2): 72-76.

Craig, R. 1982. Raw material quality control. IN Quality Control in Lumber Manufacturing. San Francisco. Brown, Terence D., Ed. Miller Freeman Publications. San Francisco, CA. pp. 50-60.

Dowdy, S. and S. Wearden. 1991. Statistics for Research. John Wiley \& Sons Inc. New York, NY.

Egan, A.F. 1999. Residual stand damage after shovel logging and conventional ground skidding in an Appalachian hardwood stand. Forest Products Journal 49(6): 88-92. 
Faust, T.D. and W.D. Greene. 1989. Effects of felling head type on tensile strength of southern pine dimension lumber. Forest Products Journal 39(11/12): 82-84.

Finley, J.C. 2002. Pennsylvania Woodlands Timber Market Report. www.cas.psu.edu/docs/CASDEPT/FOREST/TMR/2002/2-02/Prices2.html

Gallagher, T.V., R.M. Shaffer, and W.B. Stuart. 1985. An assessment of shear damage to southern pine sawlogs. Forest Products Journal 35(11/12): 87-91.

Greene, W.D. and J.F. McNeel. 1989. Potential costs of shear damage in a southern pine chip-n-saw mill. Forest Products Journal 39(5): 12-18.

Greene, W.D. and J.F. McNeel. 1987. Productivity, costs, and levels of butt damage with a Bell Model T feller-buncher. Forest Products Journal 37(11/12): 70-74.

Hanks, L. F. 1976. Hardwood tree grades for factory lumber. USDA forest Service Research Paper NE-333. Forest Service, U.S.D.A. Northeastern Forest Experiment Station. Broomall, PA.

Hanks, L.F., G.L. Gammon, R.L. Brisbin, and E.D.Rast. 1980. Hardwood log grades and lumber grade yields for factory lumber logs. Forest Service Research Paper NE-468. Forest Service, U.S.D.A. Northeastern Forest Experiment Station. Broomall, PA. 
Harlow, W.M., E.S. Harrar, J.W. Hardin, and F.M. White. 1996. Textbook of Dendrology. McGraw Hill Inc. New York, NY.

Hassler, C.C., S.T. Grushecky, and M.A. Fajvan. 1999. An assessment of stand damage following timber harvests in West Virginia. Northern Journal of Applied Forestry 16(4): 191-196.

Lamson, N.I., H.C. Smith, and G.W. Miller. 1985. Logging damage using an individuat tree selection practice in Appalachian hardwood stands. Northern Journal of Applied Forestry 2: 117-120.

McNeel, J.F. and R. Copithorne. 1996. Yarding systems and their effect on log quality and recovery levels in coastal timber of British Columbia. IN Proceedings: Forest Products Society, Portland, OR.

McNeel, J.F. and F. Czerepinski. 1987. Effect of felling head design on shear-related damage in southern yellow pine. Southern Journal of Applied Forestry (11): 3-6.

Middleton, G.R. and B.D. Munroe. 1987. Evaluating two methods of coping with tree shear damage at the sawmill. Forest Products Journal 37(7/8): 17-22. 
Murphy, G. and A.A. Twaddle. 1986. Techniques for the assessment and control of log value recovery in the New Zealand forest harvesting industry. IN Improving productivity through forest engineering: Proceedings of the $9^{\text {th }}$ Annual Council on Forest Engineering. September 29-October 2, 1985. Mobile, AL.

Pickens, J.B., A. Lee, and G.W. Lyon. 1992. Optimal bucking of Northern hardwoods. Northern Journal of Applied Forestry 9(4): 149-152.

Rast, E.D., D.L. Sonderman, and G.L. Gammon. 1971. A guide to hardwood log grading. U.S.D.A. Forest Service General Technical Report NE-1. Northeastern Forest Experiment Station. Broomall, PA.

Sessions, J. 1988. Making better tree-bucking decisions in the woods. Journal of Forestry (10): 43-45.

Seymour, R.S., P.R. Hannah, J.R. Grace, and D.A. Marquis. 1986. Silviculture: The next thirty years, the past thirty years. Journal of Forestry (6): 31-38.

Shaffer, R.M., J.A. Swiatlo, W.B. Stuart, and E.M. Wengert. 1990. An analysis of shear damage at two southern pine sawmills. Forest Products Journal 40(6): 33-36.

Shiver B.D. and B.E. Borders. 1996. Sampling Techniques for Forest Resource Inventory. John Wiley \& Sons, Inc. New York, NY. 
Visser, R., B.F. Rodgers, K. Stampfer, and T. Gallagher. 2001. Improved harvesting viability through increased value recovery. Proceedings of the $24^{\text {th }}$ Annual Council on Forest Engineering. Snoweshoe, WV.

Wenger, K.E. 1984. Forestry Handbook. John Wiley \& Sons Inc. New York, NY.

Williston, E. 1979. Opportunity areas and leverage points. IN Electronics in the sawmill. Proceedings of the electronics workshop. Sawmill and plywood clinic. Portland, Oregon. March, 1979. pp. 14-18.

Zavala, D.Z. 1995. The effect of log length and lumber thickness over-allowance on lumber recovery. Forest Products Journal 45(2): 41-45. 


\section{A P P E N D I X A : D I S T R I B U T I O N O F SA W L O G S}

Distribution of hardwoods logs across the harvest sites is broken down by species, damage extent, damage type, harvesting function, and log grade. Damage was grouped into two categories: bark damage and wood damage. Bark damage was damage to the outside of the log, without disturbing the woody tissue. Wood damage was damage to the woody tissue of the log, inside the bark. Wood damage was used in the volume loss calculations.

\section{Species}

Total saw log species distribution (Table 5.1) shows that yellow-poplar and red oak were the two most dominant species, making up over half of the data set. Black cherry, chestnut oak, and sugar maple showed similar numbers and accounted for over a third of the data set. White oak and white ash accounted for the rest of the total. Bark damage by species (Table 5.2) shows the number of logs that sustained bark damage, while wood damage by species (Table 5.3) shows the number of logs that sustained woody tissue damage. 
Table 5.1- Overall Species Composition (\# logs)

\begin{tabular}{ccccc}
\hline Species & Site 1 & Site 2 & Site 3 & Site 4 \\
\hline BC & 24 & 265 & 107 & 59 \\
CO & 290 & 16 & 37 & 4 \\
RO & 245 & 212 & 269 & 222 \\
SM & 160 & 80 & 17 & 267 \\
WA & 36 & 86 & 11 & 11 \\
WO & 51 & 34 & 15 & 62 \\
YP & 194 & 307 & 544 & 375 \\
\hline
\end{tabular}

Table 5.2 - Bark Damage Species Composition (\# logs)

\begin{tabular}{ccccc}
\hline Species & Site 1 & Site 2 & Site 3 & Site 4 \\
\hline BC & 13 & 26 & 23 & 6 \\
CO & 104 & 1 & 6 & 0 \\
RO & 74 & 26 & 34 & 36 \\
SM & 55 & 3 & 4 & 27 \\
WA & 18 & 5 & 2 & 1 \\
WO & 19 & 6 & 2 & 5 \\
YP & 42 & 16 & 64 & 49 \\
\hline
\end{tabular}


Table 5.3 - Wood Damage Species Composition (\# logs)

\begin{tabular}{ccccc}
\hline Species & Site 1 & Site 2 & Site 3 & Site 4 \\
BC & 0 & 4 & 7 & 4 \\
CO & 7 & 1 & 3 & 1 \\
RO & 8 & 4 & 21 & 19 \\
SM & 6 & 1 & 0 & 33 \\
WA & 1 & 5 & 1 & 1 \\
WO & 4 & 3 & 3 & 8 \\
YP & 12 & 5 & 38 & 31 \\
\hline
\end{tabular}

\section{Damage Extent}

Hardwood saw logs in this study were not severely damaged very often (Table 5.4). Overall, 3102 saw logs sustained no damage during this research, 667 saw logs sustained damage to the bark, and 231 saw logs sustained major damage to the woody tissue inside the bark. The important results here are the number of saw logs that sustained damage to the woody tissue due to the different harvesting operations. 
Table 5.4 - Extent of Damaged Logs (\# logs)

\begin{tabular}{ccccc}
\hline Extent & Site 1 & Site 2 & Site 3 & Site 4 \\
\hline ND & 637 & 894 & 792 & 779 \\
Bark & 325 & 83 & 135 & 124 \\
Wood & 38 & 23 & 73 & 97 \\
\hline
\end{tabular}

\section{Damage Type}

Damage type distributions show where the damage occurs across the harvesting operation. Bark damage by damage type (Table 5.5) shows that the majority of the saw logs are being damaged due to gouges caused by the mechanized harvesting system, and scrapes. Wood damage by damage type (Table 5.6) shows that the majority of the severely damaged saw logs are being damaged due to gouges, splits, slabs, and scrapes.

\begin{tabular}{|c|c|c|c|c|}
\hline \multicolumn{5}{|c|}{ Table 5.5 - Bark Damage Type Distribution (\# logs) } \\
\hline Damage Type & Site 1 & Site 2 & Site 3 & Site 4 \\
\hline GG & 324 & 40 & 52 & 76 \\
\hline SLB & 1 & 0 & 0 & 0 \\
\hline SPT & 0 & 0 & 0 & 0 \\
\hline SCP & 0 & 38 & 79 & 48 \\
\hline CKR & 0 & 5 & 4 & 0 \\
\hline
\end{tabular}




\section{Table 5.6 - Wood Damage Type Distribution (\# logs)}

\begin{tabular}{ccccc}
\hline Damage Type & Site 1 & Site 2 & Site 3 & Site 4 \\
\hline GG & 18 & 3 & 27 & 42 \\
SLB & 9 & 0 & 14 & 16 \\
SPT & 11 & 18 & 23 & 15 \\
SCP & 0 & 0 & 6 & 24 \\
CKR & 0 & 2 & 3 & 0 \\
\hline
\end{tabular}

\section{Harvesting Function}

The harvesting function distribution (Table 5.7) shows that an even number of saw logs were distributed across the four harvest sites and four harvest functions. A bark damage harvesting function distribution (Table 5.8) shows damaged log counts to be higher in the skidding and decking functions. One of the more important aspects of this project is to show differences in woody tissue damage between harvesting functions (Table 5.9). This distribution shows the greatest number of saw logs sustaining woody tissue damage due to the felling function. 
Table 5.7 - Harvesting Function Distribution (\# logs)

\begin{tabular}{ccccc}
\hline Function & Site 1 & Site 2 & Site 3 & Site 4 \\
\hline Fell & 250 & 250 & 250 & 250 \\
Skid & 250 & 250 & 250 & 250 \\
Deck & 250 & 250 & 250 & 250 \\
Load & 250 & 250 & 250 & 250 \\
\hline
\end{tabular}

Table 5.8 - Bark Damage Harvesting Function Distribution (\# logs)

\begin{tabular}{ccccc}
\hline Function & Site 1 & Site 2 & Site 3 & Site 4 \\
\hline Fell & 83 & 0 & 0 & 8 \\
Skid & 121 & 38 & 82 & 47 \\
Deck & 70 & 39 & 32 & 40 \\
Load & 51 & 6 & 21 & 29 \\
\hline
\end{tabular}




\section{Table 5.9 - Wood Damage Harvesting Function}

Distribution (\# logs)

\begin{tabular}{ccccc}
\hline Function & Site 1 & Site 2 & Site 3 & Site 4 \\
\hline Fell & 22 & 14 & 32 & 41 \\
Skid & 5 & 1 & 10 & 28 \\
Deck & 4 & 4 & 22 & 22 \\
Load & 7 & 4 & 9 & 6 \\
\hline
\end{tabular}

\section{Log Grade}

The log grade distribution (Table 5.10) shows how saw logs were distributed across the four harvest sites. A bark damage log grade distribution (Table 5.11) shows bark damaged saw log counts to be higher in grade 1 logs. The wood damage log grade distribution (Table 5.12) also shows wood damaged saw log counts to be higher in grade 1 logs.

Table 5.10 - Grade Distribution (\# logs)

\begin{tabular}{ccccc}
\hline Grade & Site 1 & Site 2 & Site 3 & Site 4 \\
\hline 1 & 445 & 558 & 583 & 379 \\
2 & 210 & 356 & 319 & 401 \\
3 & 345 & 86 & 98 & 220 \\
\hline
\end{tabular}


Table 5.11 - Bark Damage Grade Distribution (\# $\log s)$

\begin{tabular}{ccccc}
\hline Grade & Site 1 & Site 2 & Site 3 & Site 4 \\
\hline 1 & 157 & 53 & 82 & 50 \\
2 & 61 & 28 & 44 & 47 \\
3 & 107 & 2 & 9 & 27 \\
\hline
\end{tabular}

Table 5.12 - Wood Damage Grade Distribution (\# logs)

\begin{tabular}{ccccc}
\hline Grade & Site 1 & Site 2 & Site 3 & Site 4 \\
\hline 1 & 22 & 14 & 50 & 44 \\
2 & 5 & 8 & 15 & 37 \\
3 & 11 & 1 & 8 & 16 \\
\hline
\end{tabular}


Table 6.1 - Total volume by site and harvesting function (BF).

\begin{tabular}{ccccc}
\hline Function & Site 1 & Site 2 & Site 3 & Site 4 \\
\hline Fell & 33476.5 & 26667 & 32980.5 & 27462 \\
Skid & 31581 & 30581.5 & 32762.5 & 28032 \\
Deck & 21765 & 40177 & 32146.5 & 27988 \\
& & & & \\
Load & 25025.5 & 29007 & 28280.5 & 28528 \\
\hline
\end{tabular}

Table 6.2 - Total volume by site and species (BF).

\begin{tabular}{ccccc}
\hline Species & Site 1 & Site 2 & Site 3 & Site 4 \\
\hline BC & 2122 & 22828 & 12502 & 4944 \\
CO & 24684.5 & 2566.5 & 4813 & 352 \\
RO & 34997.5 & 35482.44 & 35616 & 25228 \\
SM & 14082.4 & 9890.5 & 1874 & 28231.78 \\
WA & 1957 & 10748.5 & 1730 & 1490 \\
WO & 6094 & 4128 & 2769 & 7368 \\
& & & & \\
YP & 27910.3 & 40788.5 & 66865 & 44396 \\
\hline
\end{tabular}


Table 6.3 - Total volume by site and damage type (BF).

\begin{tabular}{ccccc}
\hline Type & Site 1 & Site 2 & Site 3 & Site 4 \\
\hline ND & 68026.5 & 111201 & 97454 & 85947.07 \\
GG & 41534.5 & 6622.47 & 10650 & 13656 \\
SLB & 1335 & 0 & 1521 & 2400 \\
SPT & 952 & 2457 & 3400 & 2292 \\
SCP & 0 & 4441 & 12112 & 7714
\end{tabular}

Table 6.4 - Total volume by site and grade (BF).

\begin{tabular}{ccccc}
\hline Grade & Site1 & Site 2 & Site 3 & Site 4 \\
\hline 1 & 78679.96 & 97413.41 & 96007 & 68807.83 \\
2 & 18421 & 25474.97 & 25515 & 32241.96 \\
& & & & \\
3 & 14747 & 3543.98 & 4648 & 10960 \\
\hline
\end{tabular}


Table 7.1 - Volume loss by site and harvesting function (BF).

\begin{tabular}{ccccc}
\hline Function & Site 1 & Site 2 & Site 3 & Site 4 \\
\hline Fell & 17.5 & 272 & 274.4 & 120 \\
Skid & 4.5 & 1.5 & 2.32 & 10 \\
Deck & 5 & 9 & 17.25 & 5 \\
Load & 3.52 & 3.5 & 1.87 & 0.75 \\
\hline
\end{tabular}

Table 7.2 - Volume loss by site and species (BF).

\begin{tabular}{ccccc}
\hline Species & Site 1 & Site 2 & Site 3 & Site 4 \\
\hline BC & 0 & 28.1 & 25.79 & 1.06 \\
CO & 5.5 & 0.5 & 6 & 0.06 \\
RO & 7.09 & 5.44 & 76.67 & 15.31 \\
SM & 4.8 & 4 & 0 & 67.15 \\
WA & 2 & 157 & 17.5 & 0.5 \\
WO & 3.19 & 50.5 & 1.62 & 4.37 \\
YP & 6.99 & 40 & 168.9 & 44.56 \\
\hline
\end{tabular}


Table 7.3 - Volume loss by site and damage type (BF).

\begin{tabular}{ccccc}
\hline Type & Site 1 & Site 2 & Site 3 & Site 4 \\
ND & 0 & 0 & 0 & 0 \\
GG & 13.77 & 5.57 & 9.5 & 11.16 \\
SLB & 9.17 & 0 & 106.5 & 48.75 \\
SPT & 6.65 & 277.5 & 178.4 & 62.62 \\
SCP & 0 & 0 & 1.2 & 10.72
\end{tabular}

Table 7.4 - Volume loss by site and grade (BF).

\begin{tabular}{ccccc}
\hline Grade & Site 1 & Site 2 & Site 3 & Site 4 \\
\hline 1 & 18.2 & 179.96 & 157.4 & 75.8 \\
2 & 4.1 & 104.63 & 109.3 & 50.6 \\
3 & 7.5 & 1.04 & 29.5 & 6.82 \\
\hline
\end{tabular}


A P P E NDIX D: TOTAL VALUES FOR SAWLOGS

Table 8.1 - Total value by site and harvesting function (\$).

\begin{tabular}{crccc}
\hline Function & Site 1 & Site 2 & Site 3 & Site 4 \\
\hline \multirow{2}{*}{ Fell } & 19462 & 16653.03 & 19800 & 21563.66 \\
Skid & 19281.84 & 23472.81 & 19849 & 17659.94 \\
Deck & 10268.43 & 30336.63 & 19434 & 17700.94 \\
& & & & \\
Load & 15292.85 & 20601.36 & 15110 & 18621.54 \\
\hline
\end{tabular}

Table 8.2 - Total value by site and species (\$).

\begin{tabular}{crrrr}
\hline Species & Site 1 & Site 2 & Site 3 & Site 4 \\
\hline BC & 2460 & 26635.15 & 14965 & 5166.63 \\
CO & 5889.61 & 741.81 & 1321 & 81.76 \\
RO & 27592.64 & 29297.76 & 28423 & 19109.09 \\
SM & 14515.2 & 12664.24 & 2448 & 32207.92 \\
WA & 600.37 & 4410.94 & 781.6 & 567.22 \\
WO & 2635.37 & 1894.07 & 1357 & 3169.44 \\
YP & 10611.35 & 15417.54 & 24896 & 15243.75 \\
\hline
\end{tabular}


Table 8.3 - Total value by site and damage type (\$).

\begin{tabular}{ccccc}
\hline Type & Site 1 & Site 2 & Site 3 & Site 4 \\
ND & 39057.5979360 .38 & 56018 & 6197.06 \\
GG & 24103.48 & 5130.07 & 5923 & 9646.38 \\
SLB & 754 & 0 & 880.1 & 2559.22 \\
& & & & \\
SPT & 389.92 & 1465.61 & 2312 & 1849.44 \\
& & & & \\
SCP & 0 & 3683.61 & 8240 & 5292.8 \\
& & & & \\
CKR & 0 & 1423.81 & 818.2 & 0 \\
\hline
\end{tabular}

Table 8.4 - Total value by site and grade (\$).

\begin{tabular}{ccccc}
\hline Grade & Site 1 & Site 2 & Site 3 & Site 4 \\
\hline 1 & 52652.92 & 74596.77 & 60484 & 55798.43 \\
2 & 8743.87 & 15502.8 & 12745 & 17334.74 \\
3 & 2908.32 & 964.23 & 963.1 & 2412.87 \\
\hline
\end{tabular}


A P PENDIX E: VALUE LOSSES FOR SAWLOGS

Table 9.1 - Value loss by site and harvesting function (\$).

\begin{tabular}{ccccc}
\hline Function & Site 1 & Site 2 & Site 3 & Site 4 \\
\hline Fell & 11 & 128.31 & 140.6 & 95.71 \\
Skid & 5.19 & 0.85 & 1.26 & 5.63 \\
Deck & 0.97 & 9.32 & 9.09 & 3.44 \\
Load & 1.52 & 2.13 & 0.74 & 0.38 \\
\hline
\end{tabular}

Table 9.2 - Value loss by site and species (\$).

\begin{tabular}{ccccc}
\hline Species & Site 1 & Site 2 & Site 3 & Site 4 \\
\hline BC & 0 & 33.28 & 26.54 & 1.18 \\
CO & 1.19 & 0 & 1.03 & 0.01 \\
RO & 5.64 & 4.55 & 63.21 & 10.65 \\
SM & 5.44 & 2.8 & 0 & 75.27 \\
WA & 0.32 & 64.77 & 8.05 & 0.23 \\
WO & 1.02 & 21.25 & 0.79 & 2.13 \\
YP & 2.65 & 11.67 & 51.5 & 15.86 \\
\hline
\end{tabular}


Table 9.3 - Value loss by site and damage type (\$).

\begin{tabular}{ccccc}
\hline Type & Site 1 & Site 2 & Site 3 & Site 4 \\
ND & 0 & 0 & 0 & 0 \\
GG & 8.21 & 7.54 & 3.87 & 7.67 \\
SLB & 5.5 & 0 & 41.02 & 36.15 \\
SPT & 1.99 & 131.79 & 105.3 & 57.1 \\
SCP & 0 & 0 & 1.28 & 4.23 \\
CKR & 0 & 1.28 & 0.41 & 0 \\
\hline
\end{tabular}

Table 9.4 - Value loss by site and grade (\$).

\begin{tabular}{ccccc}
\hline Grade & Site 1 & Site 2 & Site 3 & Site 4 \\
\hline 1 & 12.89 & 101.42 & 102.8 & 71.41 \\
2 & 1.23 & 38.87 & 43.23 & 32.79 \\
3 & 1.69 & 0.43 & 5.15 & 1.25 \\
\hline
\end{tabular}


A P P E N D I X F : H A R D W O O D V O L U M E A N D VA L U E

Table 3.2 - Hardwood log volume and value.

\begin{tabular}{|c|c|c|c|c|c|}
\hline Species & Grade & $\begin{array}{c}\text { Volume } \\
\text { (BF) }\end{array}$ & $\begin{array}{c}\text { Value } \\
(\$)\end{array}$ & $\begin{array}{c}\text { Damage Volume } \\
\text { (BF) }\end{array}$ & $\begin{array}{c}\text { Damage Value } \\
(\$)\end{array}$ \\
\hline \multirow[t]{3}{*}{ Yellow-Poplar } & 1 & 134,175 & $55,011.75$ & 134,062 & $54,965.62$ \\
\hline & 2 & 35,757 & $9,654.39$ & 35,640 & $9,622.84$ \\
\hline & 3 & 10,028 & $1,504.28$ & 9,997 & $1,499.51$ \\
\hline \multirow[t]{3}{*}{ Red Oak } & 1 & 103,135 & $87,664.75$ & 103,051 & $87,593.65$ \\
\hline & 2 & 22,071 & $15,229.34$ & 22,053 & $15,217.01$ \\
\hline & 3 & 6,117 & $1,529.38$ & 6,114 & $1,528.57$ \\
\hline \multirow[t]{3}{*}{ Sugar Maple } & 1 & 33,331 & $49,330.62$ & 33,291 & $49,272.03$ \\
\hline & 2 & 15,291 & $10,704.05$ & 15,257 & $10,680.11$ \\
\hline & 3 & 5,456 & $1,800.48$ & 5,453 & $1,799.65$ \\
\hline \multirow[t]{3}{*}{ Black Cherry } & 1 & 23,739 & $32,760.51$ & 23,715 & $32,726.70$ \\
\hline & 2 & 15,477 & $15,322.23$ & 15,450 & $15,296.05$ \\
\hline & 3 & 3,180 & $1,144.80$ & 3,176 & $1,143.36$ \\
\hline \multirow[t]{3}{*}{ Chestnut oak } & 1 & 19,419 & $5,825.85$ & 19,414 & $5,824.35$ \\
\hline & 2 & 6,419 & $1,363.21$ & 6,414 & $1,362.15$ \\
\hline & 3 & 6,577 & 845.65 & 6,576 & 845.55 \\
\hline \multirow[t]{3}{*}{ White Oak } & 1 & 15,631 & $7,659.19$ & 15,600 & $7,644.45$ \\
\hline & 2 & 3,120 & $1,123.20$ & 3,091 & $1,112.89$ \\
\hline & 3 & 1,608 & 273.36 & 1607 & 273.19 \\
\hline \multirow[t]{3}{*}{ White Ash } & 1 & 11,477 & $5,279.65$ & 11,341 & $5,217.09$ \\
\hline & 2 & 3,444 & 929.88 & 3,405 & 919.35 \\
\hline & 3 & 1,004 & 150.60 & 1,002 & 150.30 \\
\hline Total & & 476,460 & $305,107.17$ & 475,716 & $304,694.48$ \\
\hline
\end{tabular}




\section{A P P E N D I X G : H A R D W O O D SA W L O G P R I C E S}

\begin{tabular}{|c|c|c|c|c|c|c|c|c|c|c|c|c|}
\hline \multicolumn{13}{|c|}{ Pennsylvania Woodlands } \\
\hline \multicolumn{13}{|c|}{ TIMBER MARKET REPORT } \\
\hline \multicolumn{13}{|c|}{ April - June 2002} \\
\hline & \multicolumn{4}{|c|}{ STUMPAGE PRICES } & \multicolumn{8}{|c|}{ MILL PRICES } \\
\hline SPECIES & $\begin{array}{c}\text { Minus } \\
1 \mathrm{St} . \\
\text { Dev. }\end{array}$ & Avg & (n)\# & $\begin{array}{l}\text { Plus } \\
1 \mathrm{St} . \\
\text { Dev. }\end{array}$ & $\begin{array}{l}\text { Low } \\
\text { F3+ }\end{array}$ & (n)\# & $\begin{array}{c}\text { Med } \\
\text { F2+ }\end{array}$ & $(\mathrm{n}) \#$ & $\begin{array}{c}\text { High } \\
\text { F1+ }\end{array}$ & (n)\# & $\begin{array}{c}\text { Veneer } \\
\text { Avg }\end{array}$ & (n)\# \\
\hline SOUTHWEST & \multicolumn{12}{|c|}{ (\$ per MBF International 1/4") } \\
\hline
\end{tabular}

\begin{tabular}{|c|c|c|c|c|c|c|c|c|c|c|c|c|}
\hline SOUTHWEST & & & & & & & & & & & & \\
\hline $\begin{array}{l}\text { Northern Red } \\
\text { Oak }\end{array}$ & 293 & 449 & (263) & 604 & 146 & (2) & 406 & (3) & 501 & (2) & 916 & (3) \\
\hline White Oak & 154 & 241 & (24) & 328 & 103 & (2) & 212 & (3) & 291 & (2) & 1065 & (2) \\
\hline Mixed Oak & 116 & 217 & (18) & 319 & 77 & (1) & 124 & (2) & 177 & (1) & 0 & (0) \\
\hline Black Cherry & 389 & 607 & (26) & 825 & 211 & (2) & 582 & (3) & 813 & (2) & 2177 & (3) \\
\hline White Ash & 74 & 175 & (21) & 277 & 90 & (2) & 162 & (3) & 269 & (2) & 1003 & (1) \\
\hline Hard Maple & 236 & 369 & (21) & 501 & 196 & (2) & 415 & (3) & 876 & (2) & 1298 & (2) \\
\hline Soft Maple & 106 & 192 & (21) & 278 & 103 & (2) & 198 & (3) & 283 & (2) & 354 & (1) \\
\hline Yellow Poplar & 64 & 161 & (21) & 258 & 90 & (2) & 162 & (3) & 239 & (2) & 0 & (0) \\
\hline $\begin{array}{l}\text { Misc. } \\
\text { Hardwoods }\end{array}$ & 37 & 119 & (23) & 201 & 77 & (1) & 108 & (1) & 0 & (0) & & \\
\hline White Pine & 49 & 63 & (6) & 77 & 88 & (1) & 108 & (1) & 0 & (0) & & \\
\hline Hemlock & 46 & 62 & (5) & 78 & 118 & (1) & 108 & (1) & 0 & (0) & & \\
\hline \multicolumn{13}{|c|}{ Conversion Factors } \\
\hline \multicolumn{13}{|c|}{ Doyle Price $=1.695 \times$ International $1 / 4 "$ Price } \\
\hline \multicolumn{13}{|c|}{ Scribner Price $=1.159 \times$ International $1 / 4 "$ Price } \\
\hline
\end{tabular}




\title{
Hardwood Log Damage Questionnaire
}

1. Do hardwood sawlogs lose value or volume due to damage caused during the hauling process?

\author{
Yes / No
}

2. During which of the following processes does the majority of damage to harvested hardwood sawlogs occur?

(Circle all that apply)
a) Felling
b) Extraction
c) Bucking
d) Decking
e) Loading
f) Hauling
g) Other

3. Which of the following are the most common types of damage to harvested hardwood sawlogs?

(Circle all that apply)
a) Barberchair
b) Felling Shatter
c) Break/Split
d) Slab
e) Saw chain cuts
f) Grapple gouge
g) Binder/Choker pinch
h) Other

4. Which of the following result in the most value or volume lost? (Circle all that apply)
a) Barberchair
b) Felling Shatter
c) Break/Split
d) Slab 
e) Saw chain cuts

f) Grapple gouge

g) Binder/Choker pinch

h) Other

5. Among all damaged hardwood sawlogs received, what is the approximate percentage of value or volume lost per log?

Value

Volume

6. Is there potential for monetary gains to be made by implementing new guidelines or training to minimize damage to harvested hardwood sawlogs?

Yes / No

7. What guidelines or training do you recommend to minimize damage to harvested hardwood sawlogs?

8. Do you have any comments or ideas on how to minimize or eliminate damage to harvested hardwood sawlogs? 


\section{A P P E N D I X I : D A T A C OLLECT I O N S HE E T}

Harvested Log Damage Data Sheet

Operation Name:

Operation Type:

Years Experience:

Harvest Type:

\section{Operation Types}

(Felling,Skidding,Bucking,Decking/Sorting,Loading)
Date:

Collector:

Site Name:

Slope/Aspect:

Damage Types ( Split, slab, gouge,

choker, scrape, no damage)

\begin{tabular}{|c|c|c|c|c|c|c|c|c|}
\hline Observation \# & $\begin{array}{l}\mathrm{DLE} \\
\text { (in) }\end{array}$ & $\begin{array}{l}\mathrm{DSE} \\
\text { (in) }\end{array}$ & \begin{tabular}{|c|}
$\begin{array}{c}\text { Log Length } \\
(\mathrm{ft})\end{array}$ \\
\end{tabular} & Species & Damage Type & D Location $(\mathrm{B}, \mathrm{M}, \mathrm{T})$ & \begin{tabular}{|c|} 
D Dimension $(\mathrm{LxW}$ W \\
(in)
\end{tabular} & Comments \\
\hline 1 & & & & & & & & \\
\hline 2 & & & & & & & & \\
\hline 3 & & & & & & & & \\
\hline 4 & & & & & & & & \\
\hline 5 & & & & & & & & \\
\hline 6 & & & & & & & & \\
\hline 7 & & & & & & & & \\
\hline 8 & & & & & & & & \\
\hline 9 & & & & & & & & \\
\hline 10 & & & & & & & & \\
\hline 11 & & & & & & & & \\
\hline 12 & & & & & & & & \\
\hline 13 & & & & & & & & \\
\hline 14 & & & & & & & & \\
\hline 15 & & & & & & & & \\
\hline 16 & & & & & & & & \\
\hline 17 & & & & & & & & \\
\hline 18 & & & & & & & & \\
\hline 19 & & & & & & & & \\
\hline 20 & & & & & & & & \\
\hline
\end{tabular}




\begin{tabular}{|c|c|c|c|c|c|c|c|c|}
\hline Observation \# & $\begin{array}{l}\text { DLE } \\
\text { (in) }\end{array}$ & $\begin{array}{l}\text { DSE } \\
\text { (in) }\end{array}$ & \begin{tabular}{|c|} 
Log Length \\
$(\mathrm{ft})$
\end{tabular} & Species & Damage Type & D Location $(\mathrm{B}, \mathrm{M}, \mathrm{T})$ & \begin{tabular}{|c} 
D Dimension $(\mathrm{LxW}$ (in) $)$ \\
(in)
\end{tabular} & Comments \\
\hline 21 & & & & & & & & \\
\hline 22 & & & & & & & & \\
\hline 23 & & & & & & & & \\
\hline 24 & & & & & & & & \\
\hline 25 & & & & & & & & \\
\hline 26 & & & & & & & & \\
\hline 27 & & & & & & & & \\
\hline 28 & & & & & & & & \\
\hline 29 & & & & & & & & \\
\hline 30 & & & & & & & & \\
\hline 31 & & & & & & & & \\
\hline 32 & & & & & & & & \\
\hline 33 & & & & & & & & \\
\hline 34 & & & & & & & & \\
\hline 35 & & & & & & & & \\
\hline 36 & & & & & & & & \\
\hline 37 & & & & & & & & \\
\hline 38 & & & & & & & & \\
\hline 39 & & & & & & & & \\
\hline 40 & & & & & & & & \\
\hline 41 & & & & & & & & \\
\hline 42 & & & & & & & & \\
\hline 43 & & & & & & & & \\
\hline 44 & & & & & & & & \\
\hline 45 & & & & & & & & \\
\hline 46 & & & & & & & & \\
\hline 47 & & & & & & & & \\
\hline 48 & & & & & & & & \\
\hline 49 & & & & & & & & \\
\hline 50 & & & & & & & & \\
\hline
\end{tabular}


A P P E N D I X J : L O G DA M A GE P ICTURES

\section{SPLITS}
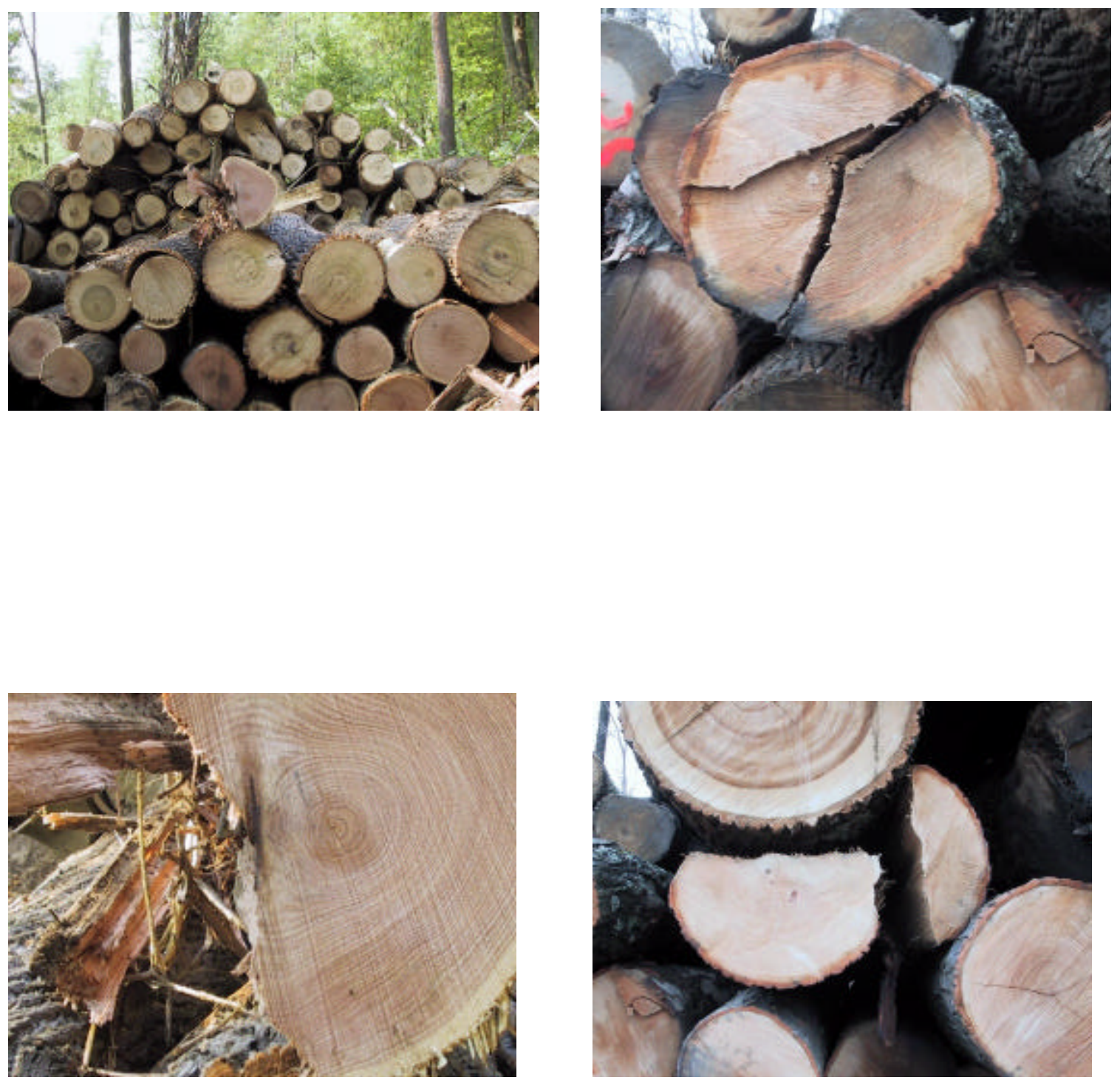
SLABS
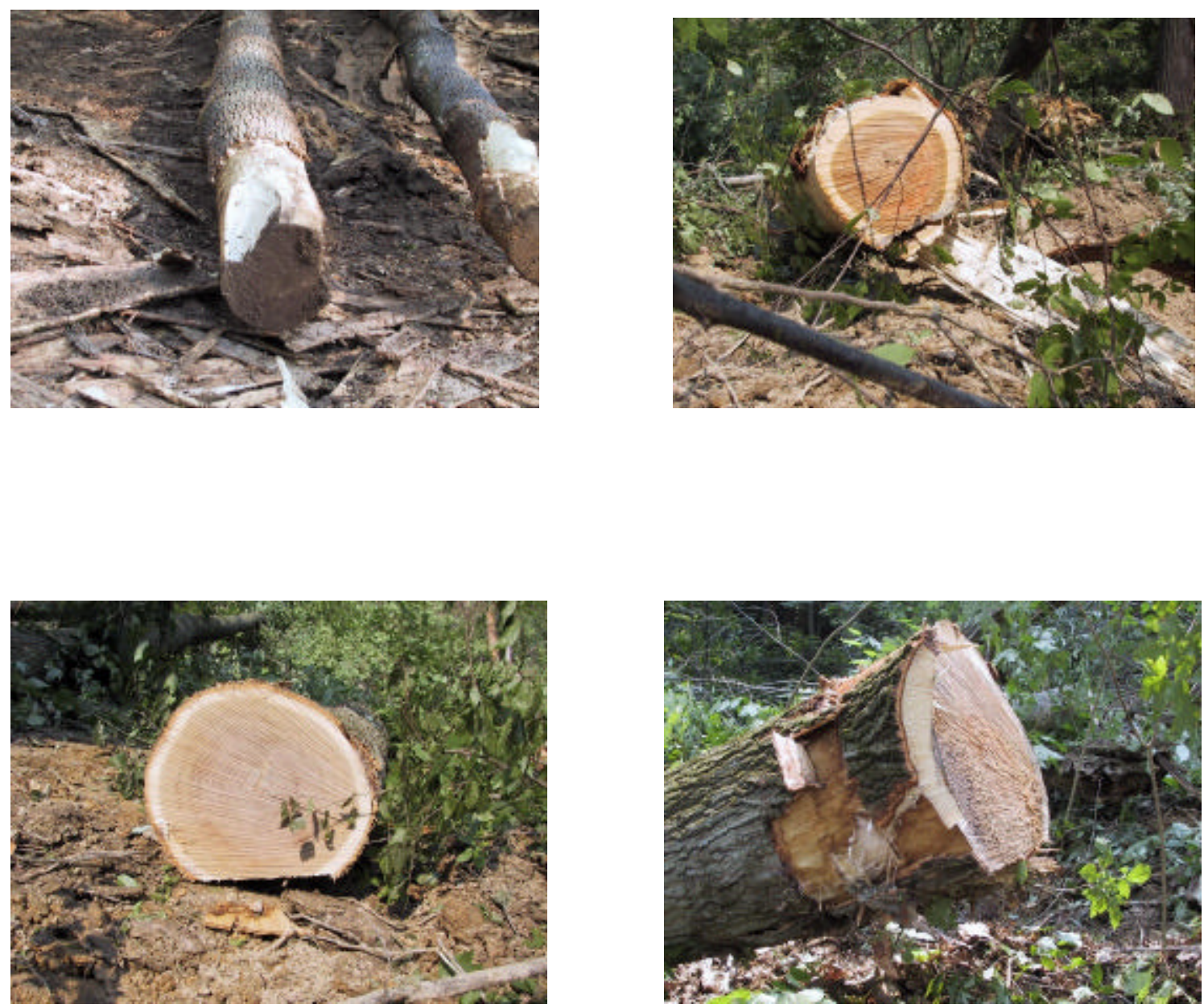
GOUGES
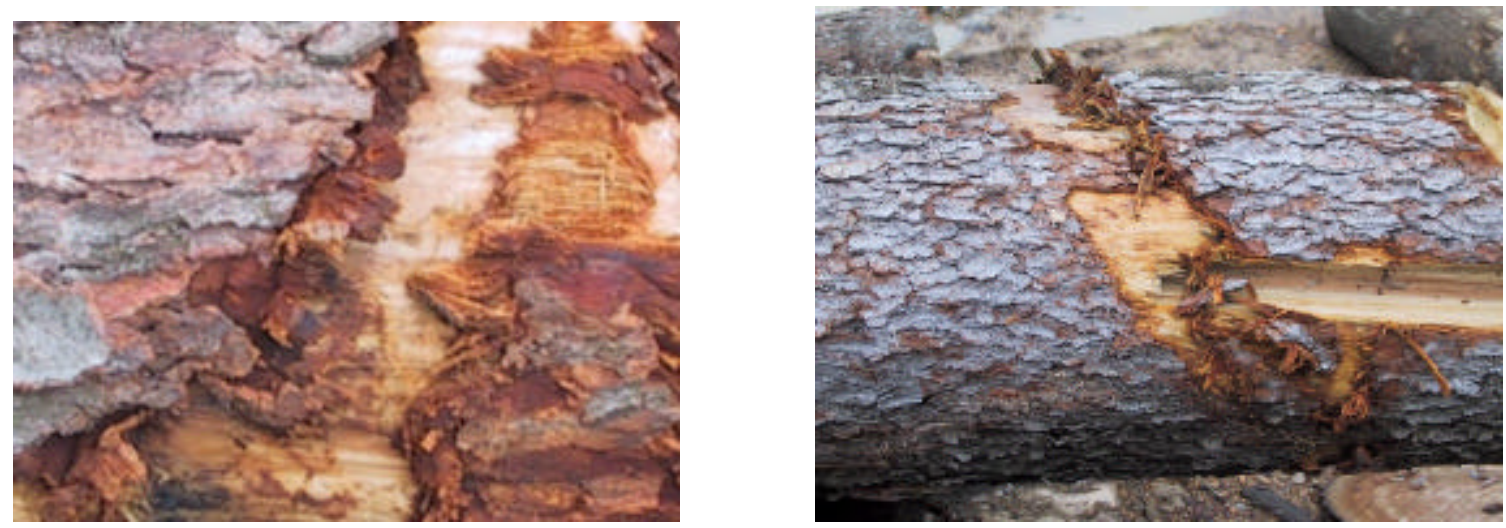

SCRAPES
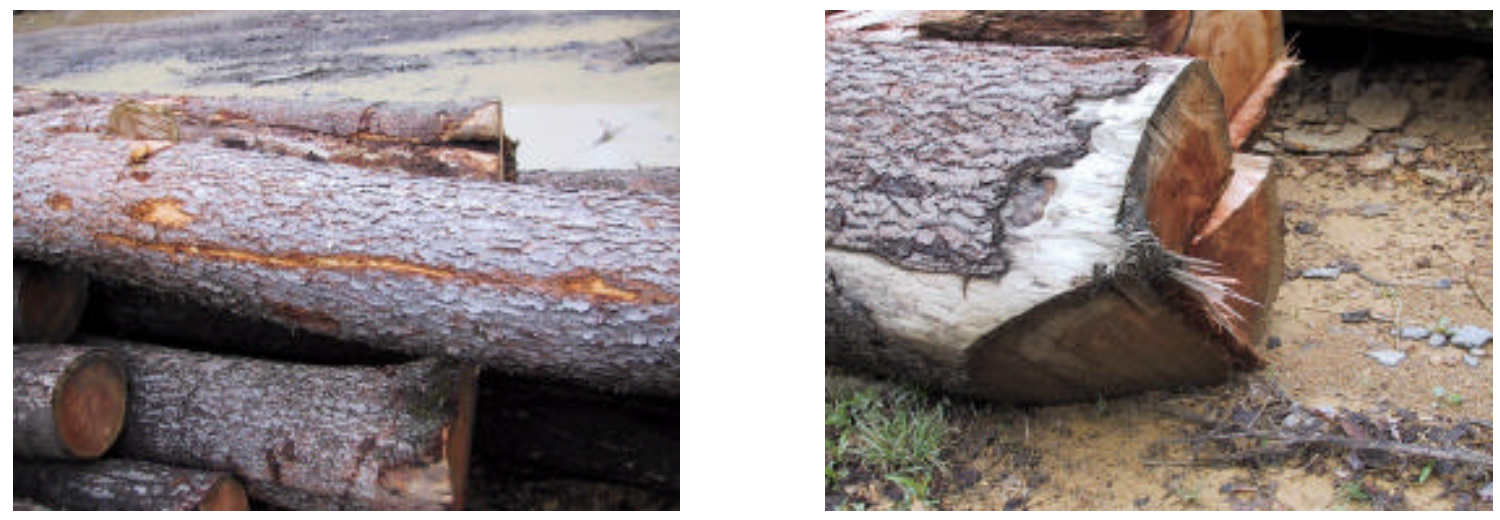
NO DAMAGE
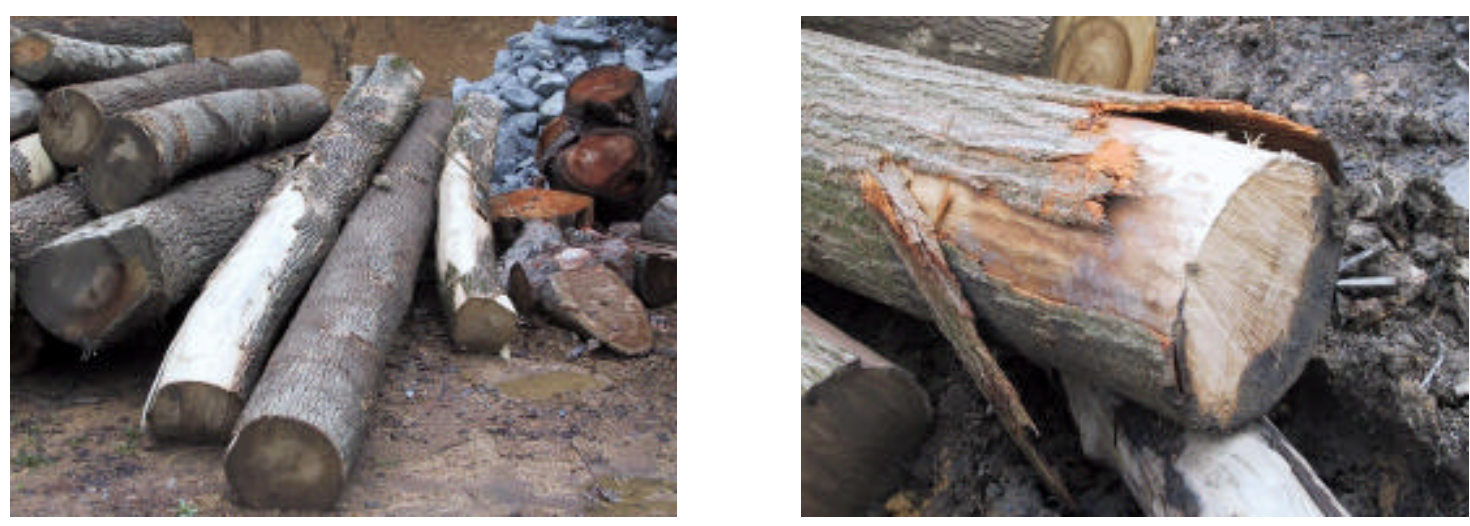